\title{
Civil Society and International Organizations: A Liberal Framework for Global Governance
}

\author{
FRANCESCA BIGNAMI*
}

Over the past two decades, a combination of social movement activists, academics, and developing countries have mounted a formidable critique of international organizations like the World Trade Organization. The bill of particulars is by now familiar to most observers: the neo-liberal formula of open markets, export-oriented economic growth, low budget deficits, minimal state intervention in the economy, deregulation, and privatization proved a disaster for most of the developing countries to which it was applied. ${ }^{1}$ The damage, while particularly acute in the developing world, was not limited to that realm. The critics have argued that even democracies in the western world have suffered at the hands of international organizations. Allegedly, such organizations sacrificed domestic concern for social and economic inequalities and environmental protection to the false regulatory imperatives of the global market.

The critique has been accompanied by a call for greater involvement, within international organizations, of civil society. ${ }^{2}$ For some, civil society means all associations between the state and the market. For the most disapproving voices, however, civil society includes only social and environmental nongovernmental organizations (NGOs) that strive to improve material conditions for the world's poor and protect the environment, not groups of firms and other market participants that seek to advance the economic interests of their members. The remedy is to curb the broad powers exercised by national ministers, international bureaucrats, and multinational corporations with the right of civil society to participate in and directly influence the decisionmaking of global institutions.

Advocates of civil society participation have already triggered a series of reforms of international organizations. A number of other reforms have not yet been adopted but are being promoted, vigorously, by academics and activists alike. Yet the justification for such far-reaching change, apart from the impulse to replace the present, state-centered configuration of international organizations

\footnotetext{
* Associate Professor, Duke University School of Law. I would like to thank Jamie Boyle, Steve Charnovitz, Xavier Lewis, Joan Magat, and Ralf Michaels for their comments. An earlier draft of this Article was presented at a faculty workshop at the University of Illinois College of Law; I am grateful to the participants for their valuable suggestions. Karin Linhart, Wilson Sumner, and Mariana Tavares provided excellent research assistance. Many thanks also to Tom Spragens for his advanced seminar on liberal democracy.

${ }^{1}$ Richard Peet, Unholy Trinity: The IMF, World BanK AND WTO 14 (2003).

2 Miles Kahler, Global Governance Redefined, WASH. U. GLOBAL StUD. L. REV. 33 (forthcoming 2005).
} 
with something different, is unclear. Why are associations outside the state better placed than trained, career civil servants and elected politicians to decide on foreign aid, regulatory pre-requisites for free trade, measures necessary to protect the environment, and other, pressing issues of global governance? And even though we might all agree that associations outside the state have something to contribute to the work of civil servants and elected politicians, what, precisely, should be their role? If the principal contribution of non-state associations is rallying the citizens of the world on international issues so citizens may hold their governments accountable, the decisions of international organizations simply need to be visible to such associations and those whom they seek to mobilize. In other words, all that is needed is greater transparency. But maybe--as most activists argue--non-state associations should also have certain, express rights to participate in the day-to-day decisions of international lawmaking bodies, bureaucracies, and tribunals. This Article seeks to fill the theoretical lacuna by advancing a normative framework for understanding whether, and how, to redesign global institutions to include civil society.

This analysis of how civil society can contribute to a better system of global governance draws on the political philosophy of civil society and the comparative law of democracy. Its first part describes the civil society phenomenon in three different international organizations: the World Bank, the World Trade Organization, and the European Union. Part Two puts forward the moral principle upon which my argument rests: liberal democracy. The next part sets the stage for the discussion of contemporary liberal theories of civil society by reviewing the history of the concept. Part Four critically examines the four dominant theories of citizen associations and their contribution to the good life in democratic societies. These theories serve as the basis for evaluating the pro-civil society reforms that have been made to date in international organizations and for suggesting additional areas of improvement. Yet the review of the literature also demonstrates, somewhat surprisingly, that the political philosophers and the civil society activists are talking past one another: the theory does not address head-on the question whether associations should be represented in public decisionmaking. For civil society theory, the democratizing potential of civil society lies in collective life outside the state. Thus, Part Five explores the comparative law of contemporary democracies and shows that interest and identity groups can participate in public life in at least three different ways: pluralism, corporatism, and republicanism. The concluding section returns to the institutional reform of international organizations. In view of the premises and ideals that inform different cultures of democracy and the realities of politics in the international realm, I argue that the public law of corporatism is the most appropriate for today's international organizations. 


\section{Reform of International Organizations}

This section canvasses some of the recent initiatives designed to include civil society--defined as all interest and identity associations outside the state--in the governance activities of international organizations. ${ }^{3}$ The purpose is not to provide an exhaustive description but rather to bring to light the scope of the civil society phenomenon and the importance of developing a theoretical framework that can assist in evaluating current and future institutional reform efforts.

\section{The World Bank}

Among international organizations, and particularly among international financial institutions, the World Bank is widely regarded as having made some of the most far-reaching reforms to accommodate civil society. ${ }^{4}$ Its efforts have extended to the policymaking, program implementation, and implementationreview functions of the Bank. Since the mid-1990s, the Bank has issued a number of policy statements promising greater NGO participation in loan decisions. ${ }^{5}$ For example, when the Bank issues a loan for a specific development project such as a dam, it requires that the recipient government consult with local residents and NGOs to design relocation plans and environmental preservation measures. ${ }^{6}$ While such loan conditions do not bring civil society directly into the Bank's decision-making process, their impact on national governments and local NGOs can be significant.

In addition to project-specific instruments, the Bank issues structural adjustment loans that are linked to the adoption of such political economy measures as exchange rate stability, low inflation, and privatization of stateowned sectors of the economy. In 1997, the Bank organized a major consultation

\footnotetext{
${ }^{3}$ This is a working definition for purposes of this Article. However, international organizations, governments, activists, and, as we shall see, political theorists, all define the term "civil society" slightly differently. While the World Trade Organization and the European Union adopt the broad definition used here, the World Bank's definition is narrower: the Bank excludes associations whose agendas are informed by the market-related activities of their members. According to the Bank's website, civil society "[refers] to the wide array of non-governmental and not-for profit organizations that have a presence in public life, expressing the interests and values of their members or others, based on ethical, cultural, political, scientific, religious or philanthropic considerations." See http://web.worldbank.org/WBSITE/EXTERNAL/TOPICS/CSO/0,,contentMDK\%3A20101499 menu PK\%3A244752 pagePK\%3A220503 piPK\%3A220476 theSitePK\%3A228717,00.html.

4 See PeEt, Unholy Trinity, supra note_ at 134; Kumi Naidoo, Civil society, governance and globalisation: The World Bank and civil society, 3 TRANSNAT'L ASS'NS 173, 179 (2003).

${ }^{5}$ See PeEt, Unholy Trinity, supra note_ at 129-30 (discussing World Bank Development Reports of the 1990s and World Bank's Comprehensive Development Framework).

${ }^{6}$ See Sabine Schlemmer-Schulte, The Impact of Civil Society on the World Bank, the International Monetary Fund, and the World Trade Organization: The Case of the World Bank, 7 ILSA J. INT'L \& COMP. L. 399, 404 (2001).
} 
exercise with governments and civil society organizations to evaluate the impact of adjustment lending and policy advice in seven recipient countries (Ghana, Uganda, Zimbabwe, Ecuador, El Salvador, Bangladesh and Hungary). The fiveyear exercise, called the Structural Adjustment Participatory Review Initiative (SAPRI), was conceived both as a vehicle for studying the effect of these loans on a number of welfare indices, such as poverty rates, productive capacity, and basic rights, and as a general examination of "how the participation of local, broad-based civil society can improve economic policymaking."7 However, after the Bank published its findings in July 2001, the NGOs involved in SAPRI issued their own, overwhelmingly negative report in April 2002, criticizing both the overall effect of structural adjustment loans on developing countries and the adequacy of the Bank's efforts to address the concerns raised by civil society. ${ }^{8}$ Despite the attempts to resolve the dispute, the Bank-sponsored process collapsed. ${ }^{9}$

The Bank's most recent efforts to involve civil society in policymaking have centered on Poverty Reduction Strategy Papers (PRSPs). Developed in collaboration with the IMF and domestic stakeholders, these papers present an overview of the economic policies, development programs, and external financing needs of specific countries, with the goal of generating a comprehensive country-based strategy for poverty reduction. ${ }^{10}$ PRSPs aim "to provide the crucial link between national public actions, donor support, and the development outcomes." 11 They are drafted through the joint effort of government officials, local World Bank officials, private sector actors, and NGOs. ${ }^{12}$ Despite its praiseworthy objectives, the initiative has invited the criticism of some civil society organizations. ${ }^{13}$ These point to instances in which governments either failed to consult NGOs, consulted them at the end of the drafting process when few changes could be made, or allowed only NGOs known to be sympathetic to the government's views to participate in the drafting process. Nevertheless, even the critics acknowledge that PRSPs represent a dramatic change from the earlier practice of deciding loan terms in exclusive, bilateral talks between the World Bank and recipient governments.

\footnotetext{
${ }^{7}$ SAPRI, Project Description of the SAPRI, available at http://www.worldbank.org/research/sapri/saprdescnew.htm.

8 SAPRIN, THE POLICY ROOTS OF ECONOMIC CRISIS AND POVERTY (2002), available at www.saprin.org/SAPRI_Findings.pdf.

${ }^{9}$ See PeEt, Unholy TRINITY, supra note _ at 144; see also SAPRIN, Letter from SAPRIN Global Steering Committee to President Wolfensohn (April 10, 2004), available at http://www.saprin.org/SAPRIN_Wolfensohn_16April04.PDF.

${ }_{10}$ See IMF, Poverty Reduction Strategy Papers, available at http://www.imf.org/external/np/exr/facts/prsp.htm.

${ }^{11} \mathrm{Id}$.

12 Id.

${ }^{13}$ See Naidoo, Civil society, governance and globalisation, supra note__ at 180.
} 
Mirroring civil society's role in loan decisions, NGO participation is contemplated in reviewing project-specific loans after their implementation. ${ }^{14}$ In 1994, the Bank created an Inspection Panel to investigate complaints that Bank officials had infringed their own procedures and rules. The multi-national, three-member Panel is appointed by the Board of Governors (composed of representatives of the member states) after consultation with the Executive Directors of the Bank (the principal governing body responsible for the day-today activities of the Bank) and civil society. ${ }^{15}$ Each member serves a single fiveyear term. More significant than the duty of civil society consultation, is the right of local NGOs to represent individuals who stood to benefit from the project and suffered injury as a consequence of the alleged violation of Bank policies. While the drafters of the Inspection Panel agreement believed that aggrieved individuals should be represented by local groups, if possible, they also stipulated that, in the absence of such groups, international NGOs could be authorized by the Bank's Board of Executive Directors to bring complaints.

In addition to these opportunities for civil society participation in Bank policymaking, the Bank seeks to foster civil society in developing countries by giving small grants to local NGOs. The Small Grants Program, managed locally by the Bank's country offices, is aimed at "promoting dialogue, disseminating information for the empowerment of marginalized and vulnerable groups, and ... enhancing partnerships with key players in support of the development process."16 The Program distributes seed money for initiatives in areas such as the environment, micro-credit, post-conflict reconstruction, information technology, human rights, gender equality, and small-enterprise development. ${ }^{17}$ The Bank also funds the Development Marketplace Program, designed to create a "marketplace of ideas" for development, in which social entrepreneurs develop and "sell" development and poverty reduction strategies to program administrators. ${ }^{18}$

The World Bank's commitment to civil society participation is also reflected in certain organizational innovations. In 2002, the Bank established a multi-tier system of Civil Society Engagement Teams. In the Bank's country offices, Civil Society Staff (CSS) are charged with encouraging civil society participation in programs funded by the Bank's trust funds. ${ }^{19}$ At the Bank's

\footnotetext{
${ }^{14}$ See Schlemmer-Schulte, The Impact of Civil Society, supra note_ at 405.

15 See Ibrahim F. I. Shihata, The World Bank Inspection Panel: In Practice 89-90 (2000).

${ }^{16}$ See World Bank, Small Grants Program, available at

http://lnweb18.worldbank.org/ESSD/sdvext.nsf/64ByDocName/SmallGrants.

${ }^{17} \mathrm{Id}$.

${ }^{18}$ See World Bank, Development Marketplace, available at http://web.worldbank.org/WBSITE/EXTERNAL/OPPORTUNITIES/GRANTS/DEVMARKETPLAC E/0,,menuPK:180652 pagePK:180657 piPK:180651 theSitePK:205098,00.html.

${ }^{19}$ See World Bank, World Bank Staff Working With Civil Society, available at http://web.worldbank.org/WBSITE/EXTERNAL/TOPICS/CSO/0,,contentMDK:20093777 menuPK:2 20425 pagePK:220503 piPK:220476 theSitePK:228717,00.html.
} 
headquarters, the staff in the Civil Society Group (CSG) advise the officials in charge of particular geographic regions, loan types, and constituencies as to the best regional strategies for involving civil society organizations. ${ }^{20}$ To coordinate initiatives at the global level, the Bank maintains a Civil Society Team (CST), comprised of staff from the Bank's External Affairs and Social Development Departments. ${ }^{21}$

A number of activists have proposed additional reforms that, in their view, would render the Bank more democratic. For instance, some have suggested increasing the representation of developing countries among the Bank's Executive Directors, since under the present system representation is tied to the size of a nation's economy. A number of critics have also called for greater access to information for civil society actors, and have advocated more robust oversight of international financial institutions by national legislatures. The Catholic development partnership CIDSE-Caritas Internationalis, for example, argues that organizations like the World Bank and the International Monetary Fund

should become more transparent by making the transcripts and minutes of board meetings available to the public and by establishing sub-boards that would monitor decisions made by the staff of the Fund and Bank. Furthermore, real democratic control over the Fund and the Bank activities is necessary through parliamentary control. Their orientations and policies should be debated in the Parliament of each member state, as currently happens in some countries. ${ }^{22}$

According to non-state actors, improvements must continue to be made if the Bank is to be considered legitimate by citizens in donor and developing countries. As the Secretary General of the World Alliance for Citizen Participation (CIVICUS), Kumi Naidoo, said in his address to the World Bank in February 2003,

[i]n order to become 'an accountable institution that is essential to poverty reduction,' as President Wolfensohn has rightly advocated, the Bank needs to be willing to bring its own decisionmaking processes into line with those it is encouraging its clients [recipient countries] to use.... Our vision should be of a world where citizens and the groups they chooses to organise are regarded as legitimate stakeholders, not only by the public,

\footnotetext{
${ }^{20}$ See id.

${ }^{21}$ See id.

${ }^{22}$ CIDSE-Caritas Internationalis, Time to reform: The International Monetary Fund and World Bank, 60 Years After 5 (September 2004).
} 
among whom they already enjoy high levels of trust, but by governance institutions who value engagement and recognize the many benefits it brings. ${ }^{23}$

\section{The World Trade Organization}

The WTO has adopted a number of transparency reforms, but it has been more reluctant to improve the opportunities for direct participation of interest and identity groups in decisionmaking. ${ }^{24}$ The Marrakesh Agreement, signed in 1994, anticipated the consultation of NGOs while leaving the details to the General Council:

The General Council may make appropriate arrangements for consultation and cooperation with non-governmental organizations concerned with matters related to those of the WTO. ${ }^{25}$

Shortly thereafter, the General Council adopted guidelines pledging to make more WTO documents available to the public and to establish an electronic, online data base for the consultation of such documents. ${ }^{26}$ The guidelines also urged the WTO Secretariat to hold periodic symposia with NGOs and to make informal arrangements to ensure that NGOs would be able to pass on information to national delegations. The General Council, however, declined to take any further steps to promote direct participation:

Members have pointed to the special character of the WTO, which is both a legally binding intergovernmental treaty of rights and obligations among its Members and a forum for negotiations. As a result of extensive discussions, there is currently a broadly held view that it would not be possible for NGOs to be directly involved in the work of the WTO or its meetings. Closer consultation and cooperation with NGOs can also be met

\footnotetext{
23 See Naidoo, supra note_181-82.

${ }^{24}$ The WTO defines "civil society" more broadly than does the World Bank: "Environmental groups, organised labour, commercial farmers and various other business lobby groups in fact all qualify for NGO status as long as they prove an interest in trade-related issues. According to one WTO official, 'Microsoft would not be allowed to attend but its industry group would be."' Mattner, Understanding NGO participation in the WTO, supra note__at 136.

${ }^{25}$ Marrakesh Agreement Establishing the World Trade Organization art. V, 2, Apr. 15, 1994, 33 I.L.M. 1125, 1146 (1994).

${ }^{26}$ Decision adopted by the General Council on 18 July 1996, Guidelines for arrangements on relations with Non-Governmental Organizations, WT/L/162, 23 July 1996; see also Decision adopted by the General Council on 14 May 2002, Procedures for the circulation and derestriction of WTO documents, WT/L/452, 16 May 2002 (deciding that all WTO official documents should be unrestricted and available to the public through WTO website).
} 
constructively through appropriate processes at the national level where lies primary reponsibility for taking into account the different elements of public interest which are brought to bear on trade policy-making. ${ }^{27}$

Today, WTO documents, including documents from Ministerials, General Council meetings, dispute resolution proceedings, and the numerous specialized committees that deal with individual trade agreements and policy areas, have become widely available. ${ }^{28}$ The changes in favor of associational participation are more limited, compared to both the transparency innovations and to the World Bank's civil society policies. NGOs may send representatives to Ministerial Conferences, where they are provided with meeting rooms and are regularly debriefed by the WTO Secretariat on the progress of the informal working sessions of the Member States, as well as the agreements ultimately reached. ${ }^{29}$ Before they may attend Ministerials, NGOs must be accredited by the WTO Secretariat, but the criteria are not particularly demanding; the Secretariat has granted about $98 \%$ of all applications to date. ${ }^{30}$ The number of accredited NGOs has grown exponentially since the practice first began--from 156 organizations in 1996 for the Singapore Ministerial Conference to 966 in 2003 for the Cancún Ministerial. ${ }^{31}$

NGOs, like other members of the public, may also file amicus briefs in WTO dispute resolution proceedings. This has been allowed since 1998, when the Appellate Body first accepted a number of amicus briefs in a case reviewing a U.S. prohibition on shrimp imported from Malaysia motivated by environmental concerns ("Shrimp-Turtle" case). ${ }^{32}$ The panels and the Appellate Body, however, retain complete discretion in allowing amici to file briefs and, of course, in allowing the views of amici to influence the outcome of cases. ${ }^{33}$

A number of scholars have proposed additional, pro-civil society reforms. To improve attention to environmental issues in the WTO, Dan Esty

\footnotetext{
${ }^{27} I$ d. at para. VI.

${ }^{28}$ See Mark Mattner, Understanding NGO participation in the WTO: history, nature and implications for developing countries, 3 TRANSNAT'L ASs'NS 132, 134 (2003).

${ }_{29}$ World Trade Organization, Relations with Non-governmental Organizations/Civil Society, available at http://www.wto.org/english/forums_e/ngo_e/intro_e.htm.

${ }^{30}$ See Mattner, supra note_ at 135. As specified in the Marrakesh Agreement, NGOs must demonstrate to the Secretariat that their work is related to WTO activities.

${ }^{31}$ World Trade Organization, Non Governmental Organizations (NGOs), available at http://www.wto.org/english/forums_e/ngo_e/ngo_e.htm.

32 See Appellate Body, United States--Import Prohibition of Certain Shrimp and Shrimp Products, para. 110, WT/DS58/AB/R (Oct. 12, 1998); see also Appellate Body, United States--Imposition of Countervailing Duties on Certain Hot-Rolled Lead and Bismuth Carbon Steel Products Originating in the United Kingdom, WT/DS138/AB/R (May 10, 2000) (holding that Appellate Body will accept and consider amicus briefs when "we find it pertinent and useful to do so"). 33 See Jeffrey L. Dunoff, Civil Society at the WTO: The Illusion of Inclusion, 7 ILSA J. INT'L \& COMP. L. 275, 277-80 (2001).
} 
recommends establishing a new advisory committee on the environment, on which business, labor, consumer, and environmental groups would sit. Esty also suggests that environmental and other groups should have the right to participate in the meetings of the WTO's Committee on Trade and the Environment, which is charged with exploring different ways of designing a common global set of trading rules that both protect the environment and promote commerce among nations. ${ }^{34}$ He would give NGOs observer status at all formal sessions of the WTO's General Council and other governing bodies. Finally, Esty argues that dispute resolution proceedings should be redesigned to afford NGOs a greater role: organizations with an interest in a particular trade dispute should have a right to submit statements to the dispute settlement panel and panels should call upon NGOs with expertise on the scientific issues underlying national environmental rules to participate in proceedings challenging such rules. ${ }^{35}$

Steve Charnovitz advocates a similar set of reforms. ${ }^{36}$ As a first step, he argues that the Committee on Trade and Development and the Committee on Trade Environment--committees that study rather than negotiate and decide matters--should allow NGOs to participate in their work. A consultative body composed of NGO representatives could be established and given the right to issue opinions on decisions taken by other WTO bodies. Charnovitz also endorses holding public hearings at which NGO representatives could appear. In sum, there is no shortage of ideas for improving civil society participation in the WTO.

\section{The European Union}

It might appear odd to speak of the role of civil society in the European Union in the same breath as that in the World Bank and the WTO. The European Union is far more than a treaty and an international organization; indeed, many would argue that it is a quasi-federal political system. Yet the European Union has faced the same criticism, even harsher at times, as international economic organizations and has come forward with a similar, though more far-reaching civil society response, as the World Bank and the WTO.

The Danish referendum on the Maastricht Treaty, which contained an ambitious new set of commitments to monetary union, a common foreign policy, and cooperation on immigration and police matters, was a watershed moment for the European Union. ${ }^{37}$ In their referendum of 1992, the Danes rejected the Maastricht Treaty, followed by an extremely narrow "yes" vote in the French

\footnotetext{
${ }^{34}$ Daniel C. Esty, Why the World Trade Organization Needs Environmental NGOs, 5 TRANSNAT'L Ass'NS 267 (1999).

${ }^{35} \mathrm{Id}$. at $275-76$.

36 See Steve Charnovitz, WTO Cosmopolitics, 34 N.Y.U.J. INT'L L. \& POL. 299, 343-44 (2002).

37 See Paul Craig \& Gráinne de Búrca, eU law: Text, Cases and Materials 22 (3d ed. 2003)
} 
referendum and widespread public debate in the United Kingdom and Germany. The Maastricht Treaty was eventually ratified, but this popular skepticism had the effect of triggering serious reflection on the normative and political underpinnings of European integration for the first time since the early 1950s. Some objections to the Treaty were fairly remote from the global governance debate: the European Union had assumed many of the powers traditionally reserved to nation states, yet it did not possess the institutions typical of a democracy, nor did it enjoy the essential premise of a democracy-government identified with a group of individuals who recognize they share enough attributes and principles to constitute a single, deliberating, and consenting "people."38 Other objections to the Treaty tracked the critique of international economic organizations mounted by the anti-globalization movement: the mission set for the European Community in 1957 was the creation of a common market--the free movement of goods, workers, services, and capital between the Member States-- and this strangely unbalanced, liberal economic agenda had the effect of burdening social welfare, environmental protection, and other policies pursued at the national level.

Since 1992, the European Union's institutions have undergone radical change, including additional, far-reaching powers for the European Parliament and significant, new transparency and access to documents standards. ${ }^{39} \mathrm{New}$ channels for civil society participation have also been added. The principal one is the European Commission's duty to consult civil society-defined as trade unions, employer federations, consumer organizations, environmental organizations, human rights organizations, charitable organizations, communitybased organizations, and religious organizations - on proposals for European legislation. ${ }^{40}$ These are the steps: The Commission describes the issues open for discussion, the public is invited to submit written comments, and the civil society responses are published. ${ }^{41}$ This process is to take place largely through the Commission's website. Then, when the Commission issues the final legislative proposal, which is transmitted to the other European lawmaking bodies for a decision, the Commission summarizes the comments and explains how the final proposal was or was not altered by the civil society responses. ${ }^{42}$ In 2003, the first year after the procedure came into force, the Commission held a total of twenty-

\footnotetext{
38 See J.H.H Weiler, The Constitution of Europe: “Do the New Clothes Have An EMPEROR?” AND OTHER ESSAYS ON EUROPEAN INTEGRATION 337 (1999).

${ }^{39}$ See Francesca Bignami, Creating European Rights: National Values and Supranational Interests, 11 COLUM. J. EUR. L. (forthcoming 2005).

${ }^{40}$ See Communication from the Commission, Toward a reinforced culture of consultation and dialogue-General principles and minimum standards for consultation of interested parties by the Commission, COM (2002) 704 final, December 11, 2002, at 6.

${ }^{41} \mathrm{Id}$. at $19-22$.

42 Id. at 22.
} 
one public consultations, evidence of the extent to which the new procedure has taken root in the Commission. ${ }^{43}$

Civil society participation also figures prominently in the Constitutional Treaty, signed in fall 2004 by European Heads of State and to be ratified within the next two years. Under Article I-47, all European institutions, not just the Commission, would have to allow civil society to participate in their government activities:

Article I-47: The principle of participatory democracy

1. The institutions shall, by appropriate means, give citizens and representative associations the opportunity to make known and publicly exchange their views on all areas of Union action.

2. The institutions shall maintain an open, transparent and regular dialogue with representative associations and civil society.

3. The Commission shall carry out broad consultations with parties concerned in order to ensure that the Union's actions are coherent and transparent.

After ratification, then, government bodies that traditionally have been closed to direct pressure from citizens and their associations will have to devise new participation procedures. These bodies include the Council of Ministers, in which government representatives from the Member States vote on legislation, and the European Courts, responsible for deciding cases brought against national governments and EU institutions for breaches of European law.

The civil society idea has thus been critical in reshaping international organizations over the past decade. But it is also an idea in flux, whose implications have not been worked out fully in the multiple, overlapping arenas of global governance. The time is ripe for examining the theoretical justifications for civil society and developing a normative framework that can guide today's global policymakers.

\section{The Morality of Liberal Democracy}

My analysis begins from the premise of liberal democracy. I employ a standard definition: terms of cooperation to which free, equal, and rational individuals living together in society could consent. ${ }^{44}$ Although contemporary philosophers dispute the nature of such terms of cooperation, most would agree that constitutional arrangements in a liberal society include, at a minimum, basic individual rights (freedom of conscience, equal treatment, property, and other

\footnotetext{
${ }^{43}$ European Commission, General Report on the Activities of the European Union 22, para. 17 (2004).

44 See John RaWls, POlitical Liberalism 16 (1993).
} 
liberties) and majority rule in certain domains of public life. ${ }^{45}$ The examination below of the political philosophy and the comparative law of civil society is limited to those thinkers and those societies that subscribe to the liberal model.

This point of departure deserves a couple words of explanation. The law that would most naturally apply to international organizations and their relations with civil society--international law--does not recognize liberal democracy as a guiding principle. Over a decade ago, Thomas Franck famously argued that a right to democratic governance was emerging in international law. ${ }^{46}$ In making his case, he looked to the practice of nations: their consent to international treaties and agreements; their willingness to respect the written rules within their territories and to monitor and enforce those rules against their nation-state neighbors; and customary international law. Yet Franck's assertion has been contested by many scholars, who point to the continuing existence of different regime types as evidence against an international consensus on democracy. ${ }^{47}$ Furthermore, even if the better scholarly view is the one that sustains an emerging right to democracy, that right would still come up short when matched against the constitutional principles of even a minimalist form of liberal democracy. In international law, democracy entails elections for government officials, but without the separation of powers and the full array of individual liberties part of the liberal tradition. ${ }^{48}$

Why, then, liberal democracy? My objective in this Article is to reflect on the moral foundations of institutions of global governance-as opposed to the modus vivendi of contemporary international relations. The liberal tradition in political philosophy, complete with its moral intuitions and its arguments from logic, offers one starting point for such an inquiry. A familiar objection is that starting with liberalism devalues other social and political experiences--those places in the world that Rawls categorizes as "decent peoples," "outlaw states," "societies burdened by unfavorable conditions" and "benevolent absolutisms."49 My response is that this Article represents but one attempt at uncovering the right and good organizing principles of international organizations; other attempts, based on alternative political traditions or on alternative readings of the liberal tradition, are by no means excluded, indeed they are welcomed.

\footnotetext{
45 See Ian Shapiro, The State of Democratic Theory, in Political ScIENCE: STATE OF THE Discipline 235, 237-44 (Ira Katznelson \& Helen V. Milner eds., 2002) (comparing deliberative democracy with Schumpeter's theory of democracy); Jeremy Waldron, Justice, in POLITICAL SCIENCE: STATE OF THE DiscipLine 266, 278-79 (Ira Katznelson \& Helen V. Milner eds., 2002) (discussing debate between Nozick and Rawls).

46 See Thomas M. Franck, The Emerging Right to Democratic Governance, 86 AM. J. INT'L. L. 46 (1992).

${ }^{47}$ See generally Benedict Kingsbury, Neo-Madisonian Global Constitutionalism: Thomas M. Franck's Democratic Cosmopolitan Prospectus for Managing Diversity and World Order in the Twenty-First Century, 35 N.Y.U. J. INT'L L. \& POL. 291, 298 (2003) (discussing debate sparked by Franck's article). 48 See Thomas Franck, Democracy as a Human Right, in HuMAn RigHTS: AN AgENDA FOR THE NeXT CEnTURy 73, 75 (Louis Henkin \& John Hargrove eds., 1994); Gregory H. Fox \& Georg Nolte, Intolerant Democracies, 36 HARV. INT'L L. J. 1 (1995).

49 See John RaWls, The LaW OF PeOPles 4 (1999).
} 
Moreover, this analysis is limited to one, narrow area of international relations: the common organizations and procedures through which today's emerging regional and global communities are governed. The normative framework developed below does not reach within the state to prescribe how political life is to be ordered; it does not carry the same threat of intervention in the affairs of sovereign nations as other universalist visions. The phenomenon of international organizations that implicate directly the rights and duties of individuals - often without real consent or mediation by the state parties to those organizations - is undeniable. What are the ramifications of one political tradition for their relations with civil society?

\section{The History of the Civil Society Idea}

Today, civil society means associational life free of the state. For most of the life of this concept, however, it meant the exact opposite: relations among citizens through the institutions of the state. ${ }^{50}$ Political theorists trace the idea to classical political philosophy, most notably, that of Aristotle. ${ }^{51}$ In the writings of the ancients, moral perfection was attained through collective life in a political community; all other human relations and allegiances were subsumed by that community.

Observation tells us that every state [polis] is an association [koinōnia] and that every association is formed with a view to some good purpose. I say 'good', because in all their actions all men do in fact aim at what they think is good. Clearly then, as all associations aim at some good, that association which is most sovereign among them all and embraces all others will aim highest, i.e. at the most sovereign of all goods. This is the association which we call the state, the association which is 'political.' [Hē koinōnia politikē which certain contemporary thinkers also translate as "civil society."] ${ }^{52}$

The social contract theorists of the seventeenth and eighteenth centuries continued to use civil society to signify political life. Civil society referred to the individual living peacefully in society with other individuals through the constitution of legitimate political authority. In the writings of Hobbes, Locke, and Rousseau, individuals in the state of nature decided by social contract to

\footnotetext{
50 See generally NOBERTo BOBbIO, Civil SOCIETy, IN DEMOCRACY AND DictATORSHIP: THE NATURE AND Limits of State Power (Peter Kennealy trans. 1989); John EhrenberG, Civil Society: The Critical History OF AN IDEA (1999); John Keane, Despotism and Democracy The Origins and Development of the Distinction Between Civil Society and the State 1750-1850, in CIVIL SOCIETY AND THE STATE: NEW EUROPEAN PERSPECTIVES 35 (John Keane ed., 1988).

51 See, e.g., EHRENBERG, CIVIL SOCIETY, supra note_at 9.

52 ARistotle, The Politics 54 (T.A. Sinclair trans. \& Revised and Re-presented by Trevor J. Saunders, Penguin Books, 1992).
} 
constitute themselves as civil society by creating a superior authority that would govern their relations. The law set down by the superior authority would discipline the relations among those individuals who were parties to the social contract. The nature of political authority was very different in the thought of the social contract theorists--absolute in Hobbes, liberal in Locke, participatory in Rousseau--but they all agreed that political authority was the necessary, defining element of civil society. "In this old European tradition," John Keane writes, "civil society was coterminous with the state." 53

Civil society [ koinōnia politiké, societas civilis, société civile, bürgerliche, Gesellschaft, Civill Society, società civile] and the state [polis, civitas, état, Staat, state, stato] were interchangeable terms. To be a member of a civil society was to be a citizen--a member of the state--and thus obligated to act in accordance with its laws and without engaging in acts harmful to other citizens. ${ }^{54}$

In the late 1700 s and early 1800 s, the meaning of the concept gradually shifted to the one employed today, that is, social relations separate from the state. The shift is associated with the rise of commerce and the growing capacity of markets to organize and shape human relations. In the thought of David Hume, Adam Smith, Adam Ferguson, and other figures of the Scottish Enlightenment, peaceful and good relations with fellow men were possible not only through politics but also through commerce..$^{55}$ According to this line of thought, civil society was possible both through politics and government and through the pursuit of individual aims in economic exchange. They had reservations about the new realm of commerce: the specialization of economic functions and the geographically distant relations associated with the age of mercantilism could bring about the corruption of man and the downfall of the community or prosperity for the nation. ${ }^{56}$ Nonetheless, the sphere of peaceful and transformative human relations expanded to included both politics and commerce. By the time Hegel published his Philosophy of Right in 1821, the analytic distinction between state and society was complete, and the language of "civil society" had come to refer, almost without exception, to human relations outside the realm of monarchy, parliaments, administration, law, courts, and the police. ${ }^{57}$

It is important to avoid anachronisms in the telling of this brief history. Although social and political philosophers of the nineteenth century agreed on

\footnotetext{
${ }^{53}$ Keane, Despotism and Democracy, supra note_at 35-36.

${ }^{54} \mathrm{Id}$.

55 See J.G.A. Pocock, The Machiavellian Moment: Florentine Political Thought and the ATLANTIC REPUBLICAN TRADITION 44-53 (1975).

56 See id. at 470-512.

57 See BOBBIO, DEMOCRACY AND DiCTATORSHIP, supra note__ at 23.
} 
the distinction between state and society, they had very different theories of the dynamics of civil society. Especially for Marx, civil society was constituted exclusively by material relations of production. Human relations through churches, voluntary associations, and social movements--considered the core of today's civil society--were insignificant in the historical materialist account of the transition from capitalism to communism and life in the communist utopia.

Choral societies, gymnastic clubs, chambers of lawyers and doctors, clubs for the abolition of luxury clothing, and other such associations that existed in the Germany of Marx's day were likewise irrelevant. ${ }^{58}$ Like the state, associational life and culture were treated as products of their materialist substructure. ${ }^{59}$ Moreover, for Marx, civil society in the here-and-now was not part of the good life. In capitalism, materialist relations of production were inherently oppressive, and it was only after revolution and the economy's transformation into a place where individuals could freely choose and combine pursuits--farmer, inventor, tradesman, and intellectual--that civil society would serve as an arena for self-expression and cooperative relations with one's fellow human beings. ${ }^{60}$

The account of civil society by Marxist theorist Antonio Gramsci, who is still influential in contemporary European intellectual circles, was far more variegated than that of Marx. ${ }^{61}$ Gramsci posited that the civil sphere was distinct from the economic sphere and that this separation gave civil society a significant degree of autonomy from the relations of production in the economic sphere. Civil society encompassed a wide array of values, ideologies, beliefs and voluntary associations, not just those of the dominant economic class. Hence, even though the beliefs and ideologies of the bourgeoisie might be hegemonic, they were subject to challenge from other cultural forces. In stark contrast to the theories of Marx, this contention was vital to the fall of capitalism and the disappearance of the state.

In contrast to Marx, Alexis de Tocqueville attributed significant importance to associations outside the market. Tocqueville observed voluntary associations of all stripes in nineteenth-century American communities. These, he claimed in Democracy in America, were essential to the success of national and

\footnotetext{
${ }^{58}$ See generally Klaus Tenfelde, Civil Society and the Middle Classes in Nineteenth-Century Germany, in

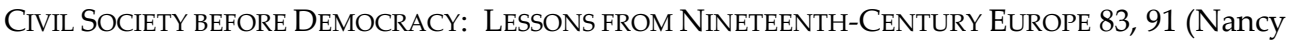
Bermeo \& Philip Nord eds., 2000).

${ }^{59}$ See Noberto Bobbio, Gramsci and the Concept of Civil Society, in Civil Society AND THE STATE: New European Perspectives 73, 82 (John Keane ed., 1988).

${ }^{60}$ See Karl Marx, The German Ideology: Part I, in THE MARX-Engels ReAder 146, 197 (Robert C. Tucker ed., 2d ed. 1978).

${ }^{61}$ See Bobbio, Gramsci and the Concept of Civil Society, supra note_ at 88-96; Kai Nielsen, Reconceptualizing Civil Society for Now: Some Somewhat Gramscian Turnings, in TOWARD A GLOBAL Civil Society 41, 43 (Michael Walzer ed. 1995).
} 
state government: they were the "great free schools to which all citizens come to be taught the general theory of association." 62

\section{Civil Society in Contemporary Theories of Democracy}

Over the past fifteen years or so, the concept of civil society has experienced a revival. ${ }^{63}$ It has surfaced in the analysis of government and public life in virtually all parts of the world: Eastern Europe, Latin America, Africa, Asia, Western democracies, and international regimes. Most scholars in the social sciences and political philosophy who analyze this phenomenon argue that associations outside the state are key to individual freedom and good government. Without civil society, they argue, individuals are incapable of fulfilling their essential capacities, and life with their fellow human-beings-society--is impossible or unsatisfactory. Scholars are divided, however, on what they consider to be "liberty" and the contribution of society and government to its pursuit. Their assessment of these fundamental questions leads to different definitions of civil society and different prescriptions for the public policy of civil society. This section reviews the four types of claims for how associational life outside the state contributes to liberal democracy, claims that can be loosely identified with four different theories of government: liberal, republican, communitarian, and cosmopolitan. ${ }^{64}$ The purpose is three-fold: to bring to light the reasons for giving civil society pride of place in good, global governance, to draw out the policy implications of the theories, and to expose the shortcomings of the existing theories in addressing today's question of the appropriate role for civil society in global governance.

\section{Liberal Theory}

\footnotetext{
62 Alexis de Tocqueville, Democracy in America 522 (J.P. Mayer ed., George Lawrence trans., Perennial Classics 2000) (1850).

63 See Michael Edwards, Civil Society 2 (2004); OMAR G. EnCARnaCiOn, THE MYTH Of Civil SOCIETY: SOCIAL CAPITAL AND DEMOCRATIC CONSOLIDATION IN SPAIN AND BRAZIL 18-20 (2003); John Keane, Civil SOCIETY: Old IMAGES, NEW Visions 4 (1998).

${ }^{64}$ In this section, I draw upon scholarship from around the world when examining new democracies, but otherwise I rely heavily on empirical and normative theories developed by American scholars. Since this paper is aimed at the global sphere, scholarly literature from old democracies other than the United States would also be highly relevant, but it does not appear that the vicissitudes of associational life have undergone the same empirical scrutiny or have inspired the same theorizing in European countries and other long-standing democracies. Some European scholars have analyzed the decline of political parties as vehicles for citizen participation in national politics and the corresponding proliferation of issue-specific associations. See, e.g., ROGER SuE, LA SOCIÉTÉ CIVILE FACE AU POUVOIR 23-25, 81-84 (2003). However, they do not focus on associationalism outside the state, as does the theory considered in this section. Rather, Sue and others argue for a more prominent role for voluntary associations in legislative and administrative decisionmaking on the grounds that the new associations are more representative of citizens than the old system of political parties and elections. Part Three takes up this argument and I postpone my discussion of it until then.
} 
The liberal strand of civil society thinking is inspired by the transition over the past three decades from dictatorship to democracy. This is what Samuel Huntington famously called the "Third Wave" of democratization in countries around the world: Spain and Portugal in the 1970s; Argentina, Brazil, and Uruguay as well as countries in Africa and Asia in the 1980s; the countries of Eastern Europe and the former Soviet Union in the 1990s. Much empirical analysis of new democracies makes the case that associational life outside the state was critical in enabling democracy to take hold. In these accounts of democratization, the collapse of dictatorship was preceded by a rise in the number of voluntary associations, churches, social movements, and other forms of organized social life, all subsumed under the category of "civil society." For instance, scholars of Polish politics link the fall of the Communist government in 1989 to the proliferation of underground dissident groups, the rise of the trade union movement "Solidarity," and the growing independence of the Catholic Church in the 1970s and 1980s. ${ }^{65}$

The liberal justification for civil society rests on a vision of politics in which the ability to choose freely one's life projects is critical to liberty and in which the possibility of conflict among different life projects is healthy, not cause for concern. ${ }^{66}$ The fact that my desire to develop my capacities and use my resources can conflict with those very same desires in my neighbor does not pose an intractable problem for peaceful, public life or for the basic liberty of others to pursue their self-chosen ends. In the liberal theory of politics, organizations and groups independent of the state constitute arenas in which different interests, identities, and aspirations can flourish. A pluralistic civil society is an end in and of itself because the many associations of civil society enable individuals to pursue their self-chosen life projects; pluralism is necessary to liberty. Civil society also serves the consequentialist purpose of checking state power and thereby contributing to democracy. Private organizations constitute centers of power that compete with the state and can thus curb the excesses of electoral and bureaucratic politics. Furthermore, through the associational life of civil society, citizens can examine government policy critically and mobilize for and against the hundreds of choices made every day by elected and appointed public officials.

The importance liberal thinkers attach to pluralism and the different visions of the good life leads them to adopt a highly inclusive definition of civil

\footnotetext{
${ }^{65}$ See, e.g., GReGor EKIERT \& JAN Kubic, Rebellious Civil Society: Popular Protest AND Democratic Consolidation in POLAND, 1989-93, at 44 (1999).

${ }^{66}$ See Michael Walzer, The Idea of Civil Society: A Path to Social Reconstruction, in COMMUNITY WORKS 123, 132 (E.J. Dionne ed., 1998); Michael Walzer, The Concept of Civil Society, in TOWARD A GLOBAL CIVIL SOCIETY 7, 18, 25 (Michael Walzer ed. 1995); Terry Nardin, Private and Public Roles in Civil Society, in TOWARD A GLOBAL CIVIL SOCIETY 29, 30, 33 (Michael Walzer ed., 1995) (identifying "liberal" and "communitarian" strands in Walzer's exposition of civil society and putting forward a pure liberal argument).
} 
society. All purposes and all modes through which individuals combine to further those purposes fit within the definition, as long as the organization is not part of the coercive apparatus of the state. Market-based organizations-corporations, labor unions, employer associations, and industry lobbies--as well as families, neighborhood watches, veterans associations, and environmental groups, all count as civil society. ${ }^{67}$

The liberal model generates a number of prescriptions for the public policy of civil society. Foremost among these, the state must guarantee the fundamental rights of free speech and free association. ${ }^{68}$ Without these rights, individuals cannot pursue their diverse aims with other, like-minded individuals, and civil society cannot criticize, oppose, and check state authority. Some thinkers in the liberal tradition go further. Michael Walzer, for instance, praises the associational life of civil society as "the actual ground where versions of the good are worked out and tested ... and proved to be partial, incomplete, ultimately unsatisfying."69 But he also cautions that "civil society, left to itself, generates radically unequal power relationships, which only state power can challenge."70 Unlike other liberal thinkers, Walzer is concerned that the exercise of liberty by one individual or group of individuals might diminish that of others, and he believes that the state can mediate among conflicting liberty claims without degenerating into authoritarianism. Hence, Walzer adds another set of policy recommendations to the basic package of liberal rights. He advocates a host of redistributive measures to enable those voluntary associations disadvantaged by the inequitable distribution of material and moral resources in contemporary societies--working families, consumer cooperatives, labor unions, ethnic minorities, and the like--to further their ends and participate in democratic life. ${ }^{71}$

\section{Republican Theory}

The republican justification for civil society is tied to the experience with associational life in old, western democracies. In contrast to the studies of new democracies, those of old democracies, mostly notably Robert Putnam's magisterial review of American associational life in Bowling Alone, have shown that membership in voluntary organizations is on the decline. ${ }^{72}$ In Bowling Alone, Putnam demonstrates that, since the 1960s, membership in all types of

\footnotetext{
${ }^{67}$ Walzer, The Concept of Civil Society, supra note_at 19.

${ }^{68}$ See, e.g., Mark Tushnet, The Constitution of Civil Society, 75 CHI.-KENT L. REv. 379, 398-99 (2000) (analyzing importance of First Amendment rights of speech and association for civil society).

${ }^{69}$ Walzer, The Concept of Civil Society, supra note_ at 17.

${ }^{70} \mathrm{Id}$. at 23.

${ }^{71} \mathrm{Id}$. at 23.

72 Robert D. Putnam, Bowling Alone: The Collapse and Revival of American Community (2000). For a critical examination of Putnam's findings see RICHARD POSNER, PUBLIC InTELLECTUALS: A STUDY OF DECLINE 311 n. 63 (2001).
} 
organizations has dwindled, both in those directly engaged in civic life such as the League of Women's Voters and those with recreational or other purposes with little apparent connection to civic life, such as local singing clubs.

This phenomenon is troubling to Putnam and others because, in their view, joining and participating in voluntary organizations trains men and women for citizenship. In contrast to the liberal vision of democracy, the republican model perceives a tension between the fulfillment of self-chosen aims and the peaceful and prosperous ordering of public affairs. The pursuit of selfinterest and particularistic identities can precipitate the breakdown of community - through civil war or, less dramatically, through ineffective government, which, unable to provide basic public goods such as clean water and healthcare in turn compromises liberty. In the republican vision, for society to be possible and for government to work, individuals must learn certain skills and virtues of citizenship--skills and virtues that redefine the concept of individual liberty. And, according to Putnam and others, the voluntary associations of civil society is where this learning occurs. Putnam articulates this understanding of the relationship between liberty and good government as social capital: in the small-scale setting of the bowling league or the local union organization, individuals learn the habits of cooperation, reciprocity, and trust that are necessary for all collective endeavors, including good government. These habits, critical for organizing soccer games and neighborhood watches, are likewise critical for voting for national representatives and engaging in public debate with fellow citizens and public officials on the pressing matters of the day. ${ }^{73}$

Modern day civil society enthusiasts might be surprised to hear that they fit within a republican tradition that can be traced back to the classical Greek and Roman republics, the civic humanists of the Italian Renaissance, and Rousseau. ${ }^{74}$ The analytical concept of social capital, based upon contemporary game theory and the strategies necessary for overcoming the collective action dilemma identified by game theory, appears a long way off from the republican virtue of active citizenship. Perhaps even more puzzling than this identification of social capital with republicanism is the well-known republican suspicion of intermediate groups, a suspicion that such associations may command the loyalties of citizens at the expense of their loyalties to the association of the whole, namely the state. Nevertheless, the new idea of civil society as the incubator of civic virtue necessary for democracy shares basic, common premises with the old concept of republican democracy. In both, the individual pursuit of particularized interests creates difficulties for government. The answer for both is the creation of a common reservoir of values and aspirations, albeit through

\footnotetext{
73 See id. at 18-24; Robert D. Putnam, Making Democracy Work: Civic Traditions in Modern ITALY (1993).

74 See David Held, Models of Democracy 36 (2d ed. 1996); Noberto Bobbio \& Maurizio Viroli, THE IDEA OF THE REPUBLIC 8-14 (Allan Cameron trans. 2003).
} 
slightly different means: experience in the voluntary associations of civil society in the social capital school of thought, and education in civic and moral virtues in the republican one.

Republican theory, more selective than liberal theory in defining the ambit of civil society, generally excludes two types of associations whose aims and internal structure are such that they cannot serve as incubators of the reciprocity and trust skills necessary to the pursuit of public aims. The first are market actors--corporations, partnerships, other profit-seeking entities, and the small, specialized pressure groups that represent their interests in public life..$^{75}$ Maximizing profits in capitalist markets and influencing politics to the material advantage of corporations do not require reciprocity and trust and hence do not lead to the creation of social capital. In collective behavior oriented towards markets, the material rewards of success are immediate enough that the participants need not develop the norms necessary to sustain collective action and achieve success in other spheres. Furthermore, the rigidly hierarchical internal structure of most large economic entities enables them to pursue goals without developing social capital among their employees. ${ }^{76}$ Hierarchy exists because those at the top have numerous material incentives to induce compliance from those at the bottom. In other words, hierarchical organizations can rely more heavily than other organizational forms on the concentration of material resources among their governing members--e.g. the power to hire and fire, set salaries, and decide on office space--to induce others to further the organization's aims. Therefore, these organizations can survive without the social capital that is vital to other associations.

The second type of association that republican theorists exclude from the ambit of civil society is the specialized organization that focuses on political advocacy and that has neither a rank-and-file membership nor the capacity to mobilize large numbers of individuals when necessary. ${ }^{77}$ Like firms, the internal dynamics of small pressure groups, whether they fall into the private- or publicinterest categories, are not conducive to building social capital and fostering civic-minded individuals. That is because the professionals who staff the national offices of organizations such as the Center for Science in the Public Interest (a foundation-funded, pro-consumer group) or Citizens for a Sound Economy (a corporate-funded, anti-big government group) have very little daily

\footnotetext{
75 See Putnam, Bowling Alone, supra note_ at 91-92 (describing features of employment relationship that undermine social capital).

${ }^{76}$ Some economists argue that forms of economic organization other than firms and corporations-for instance market-based contracting relations and networks--depend on social capital. See, e.g., James Podolny \& Karen L. Page, Network Forms of Organization, 24 ANN. REV. OF Soc. 57 (1998). In this paper I do not enter into that debate, so I leave open the question of whether firms that engage primarily in the network form of economic organization can be considered part of civil society. 77 PutnAM, BOWLing AlONE, supra note__at 52 (discussing low social capital value of lobbying groups ranging from the American Association of Retired Persons, the American Automotive Association, the National Wildlife Federation, and the National Rifle Association).
} 
connection to the individuals and the interests they represent. Citizens might agree with their political aims and even donate money to their causes, but it is unlikely that citizens will be spurred by such organizations to engage in other forms of civic action.

The republican justification for civil society, like the liberal one, gives rise to a number of public policy recommendations. Many of them are directed at individual citizens, rather than at government policymakers, on the theory that social capital must, at least in part, be rebuilt from below, through the personal choice to join and participate in community life and voluntary associations. ${ }^{78}$ Some of the recommendations, however, are directed at statesmen, too. In Better Together, the policy-oriented book that followed on the heels of the rich, empirical case for social capital in Bowling Alone, Putnam makes a number of procivil society suggestions for statesmen: ${ }^{79}$ The tax code, through deductions and other incentives for donations to voluntary organizations, can promote civil society. Smart urban planning can enable individuals to spend less time commuting and more time participating in associations. Employment and labor laws that would allow working parents to demand flexible work schedules can help citizens spend more time with their children and become involved in community initiatives. Public investment in education creates one of the important pre-conditions for participating in associational life and developing social capital. Local government institutions and procedures that give grassroots associations a say in public decisionmaking can create incentives for such associations to form in the first place. Reflecting on a civil society experience in Portland, Oregon, Putnam says: "By opening up to local organizations and giving them responsibility, government created an incentive for local organization. On the other hand, the fact that activists pressured the city government to give them a voice was integral to that development." simply, government can promote civil society by giving citizen associations legal powers and tax dollars that ordinarily would be used and spent by public officials. For example, Putnam cites these pro-civil society government policies: the decision of the City of Boston to delegate the power of eminent domain to allow a local neighbor association to purchase and develop land in central Boston; state and federal funding for a tutoring program in Philadelphia sponsored and run by a local volunteer group; state funding for a jobs program and a sewer system that were the object of a grassroots faith-based campaign in Texas.

Harvard sociologist Theda Skocpol has developed an important critique of Putnam's thesis and has put forward her own--still fundamentally republican-

\footnotetext{
78 See Saguaro Seminar: Civic Engagement in America, 150 Things You Can Do To Build Social Capital, available at http://www.bettertogether.org.

79 See Robert Putnam, Better Together 271-79 (2003).

80 See Putnam, Better Together, supra note__ at 273.
} 
-model of civil society. ${ }^{81}$ Skocpol argues, contra Putnam, that what is troublesome about the history of twentieth-century American civic life is not the decline in the absolute number of associations and membership, but the decline in a certain type of association and membership: nationwide organizations with local chapters that mobilize citizens from many different walks of life in the pursuit of common goals, such as the Order of the Sons of Temperance, the Young Men's Christian Association, and the National Congress of Mothers (PTA). ${ }^{82}$

The decline in large membership associations is troubling to Skocpol because for national government to work, citizens must develop solidarities and institutional structures than enable them to join together with their counterparts across the nation to press for common causes. As in the standard republican account, Skocpol believes that civil society can overcome the tension between the pursuit of self-chosen aims and the good life in a society. However, Skocpol argues that in a political system that is national in scope, civil society must also be national, for otherwise elites will be able to act without any contribution from the broad mass of citizens scattered throughout the nation and disempowered by the lack of an associational connective tissue. Without truly national citizenship, elites will inevitably make public decisions to further their own ends and not those of ordinary people. This goes for associational elites as much as for economic and government ones: with the current trend toward the professionalization of citizen advocacy groups, the post-material values of the upper-middle class professionals who staff and donate to public interest groups drown out the social justice concerns of the working class. ${ }^{83}$

Skocpol's understanding of the contribution associations make to national democracy leads to her to define civil society somewhat differently from the social capital theorists. Although, like them, she excludes profit-making entities and their associations as well as small, professionalized pressure groups without a membership base, she also excludes purely local groups that have no ambition to engage in public debate or to take part in civic life beyond the neighborhood or town. ${ }^{84}$

As for the prescriptive part of Skocpol's analysis, she makes a number of recommendations "designed to get broadly organized groups of people into politics." ${ }^{85}$ In marked contrast with Putnam's approach, her proposals are designed to foster associations that pursue a particular type of aim--political--and that do so by mobilizing and involving citizens on a nation-wide basis. This, Skocpol argues, might be accomplished by repealing laws currently on the books that prohibit

\footnotetext{
${ }^{81}$ See Theda SKocpol, Diminished Democracy: From Membership to MANAGEMENT IN AMERICAN Civic LIFE (2003).

${ }^{82}$ See id. at 26-27.

${ }^{83}$ See id. at 240.

${ }^{84}$ See id. at 12-13, 227.

${ }^{85} \mathrm{See}$ id. at 283.
} 
associations from donating to political campaigns and that discourage associations from fostering political debate among their members and from engaging in partisan politics. ${ }^{86}$ In addition, Skocpol suggests that civil society, as well as national democratic politics, might be strengthened by procedures that give associations with significant and far-flung memberships a special place in legislative deliberations in Congress. ${ }^{87}$

\section{Communitarian Theory}

Communitarian theories of civil society, like republican ones, have become salient in contemporary academic and political debates because of the impoverished state of associational life in modern-day America. ${ }^{88}$ Unlike republicans, however, communitarians do not simply perceive a tension between the choice and realization of personal life projects and a stable and prosperous political community; rather, they deny that such choices are ever made independent of the wider social and political community to which individuals belong. Individual identities are constituted by the spheres of family, neighborhood, and associations--otherwise known as civil society--that individuals inhabit. ${ }^{89}$ The leading communitarian theorist Amitai Etzioni elaborates on this perspective from the viewpoint of society, as opposed to individual identity:

[A] well-functioning society, let alone a good one, requires a core of substantive (rather than merely procedural) shared values, which in part define not only public but also private proper behavior. These values are transmitted from generation to generation by the family, schools, and the community (including its places of worship and civic associations). Moral dialogues then recast values bequeathed by earlier generations. ${ }^{90}$

Because of this theory of individual liberty and political community, the decline of associational life in contemporary American is an especially urgent problem

\footnotetext{
86 Skocpol also puts forward a series of bottom-up proposals, aimed at citizens and activists. Chief among them is to mobilize locally and develop a solid, nationwide following, while at the same time lobbying at the federal level, in Washington, D.C. See id. at 266-76.

${ }^{87}$ See id. at 289.

88 See, e.g., Council on Civil Society, A Call to Civil Society: Why Democracy NeEds Moral TruTHS (1998); Jean Bethke Elshtain, Will the Real Civil Society Advocates Please Stand Up?, 75 CHIKent L. ReVieW 583 (2000); JeAn BethKe Elshtain, Democracy on Trial (1995); William Galston, Liberal Purposes (1991); Michael S. Joyce \& William A. Schambra, A New Civic Life, in Peter L Berger \& Richard John Neuhaus, To Empower People: From State to Civil Society 11, $27-29$ (Michael Novak ed., 2d ed. 1996) (expounding a conservative communitarian view). ${ }^{89}$ See Susan Williams, A Feminist Reassessment of Civil Society, 72 IND. L. J. 417, 419 (1997). ${ }^{90}$ See Amitai Etzioni, Law in Civil Society, Good Society, and the Prescriptive State, 75 CHI.-KENT L. REV. 355 (2000).
} 
for communitarians. The personal and collective good lives are inextricably intertwined, and both are inconceivable without a civil society that nurtures and imparts certain core values.

Given the communitarian conceptualization of civil society, the understanding of which associations count as civil society differs from that of liberal and republican theories. Civil society in communitarian thinking is mainly local--family, neighborhood, and town--for only in those settings are relations with others so thick and frequent that personhood is shaped by community. The public policy recommendations made by communitarians are designed to foster this form of local associationalism. First, they advocate a retreat of the state from social life. ${ }^{11}$ Communitarians oppose the social welfare programs established in the 1960s on the grounds that such programs attempted to replace the family, community, and church with the state and public bureaucracies and that, in doing so, undermined America's social fabric. Many believe that legislation like Aid to Families with Dependent Children did more to harm than to improve the individual life chances of welfare recipients. By returning social responsibility to families and local communities, reformers on the right believe that their particular form of civil society will be revived. Second, to the extent that federal and state governments continue to exercise authority in areas such as welfare and education, communitarian reformers argue that the tax dollars and legal powers of the state should go directly to local charities, churches, and communities. This would be achieved through policy instruments such as tax deductions for donations to charities ${ }^{92}$ and federal grants to churches and local philanthropic associations that provide social services. ${ }^{93}$

As Skocpol notes, the communitarian and social capital schools of thought share a certain affinity. ${ }^{94}$ Both communitarians and social capitalists argue that good government is predicated upon the thick, interpersonal relations that are found most often at the local level; therefore both gravitate to many of the same prescriptions for individual action and government reform. Nonetheless, the critical difference that separates the two should also be appreciated: communitarians identify a specific list of values that the associations of civil society are to promote--values such as devotion to one's children and parents, giving to the less fortunate, and belief in God--while republicans avoid

\footnotetext{
${ }^{91}$ David Boaz, Expansive Solutions, Washington Post, Sept. 27, 1995 ("The message of 1994--like the message of 1776 and 1789, one might add--is not that the federal government should rebuild families and communities. It is that federal government should get out of their lives.").

92 See Senator Dan Coats, Can Congress Revive Civil Society?, Pol'y ReV., Jan.-Feb. 1996, No. 75, p. 25.

93 See Foreword by President George W. Bush, in The White House, RALlying the ARMies OF COMPASSION (2001). Skocpol argues convincingly that such efforts will simply lead to the bureaucratization and professionalization of voluntary associations and therefore will be selfdefeating insofar as they are designed to strengthen civil society. See Skocpol, supra note__ at 26065.

94 See SKOCPOL, DiMINISHED DEMOCRACY, supra note_ at 9.
} 
privileging one set of ends over another, except for the fundamental civic virtues of cooperation and trust. ${ }^{95}$

\section{Cosmopolitan Theory}

Cosmopolitan theorists--analysts of systems of government that extend beyond the nation-state--make yet a fourth set of arguments on the interrelated issues of the democratizing effects of civil society, the organizations that count as civil society, and the policy measures that should be adopted in favor civil society. Just as liberal theorists are impressed by the resurgence of civil society in the Third Wave of democratization, and republican and communitarian theorists are troubled by the decline of civic life in the United States, cosmopolitan theorists are stirred by the rise of associations and social movements that span the globe. Associations and informal networks that mobilize individuals across national borders, focus on global issues, and target multiple countries and multilateral regimes in order to achieve their goals, are multiplying. ${ }^{96}$ This phenomenon includes long-standing organizations, such as Amnesty International and the World Wildlife Fund, as well as more spontaneous social movements, such as the anti-globalization networks responsible for the protests at the WTO ministerial in Seattle. Cosmopolitan theorists hope that the new, world-wide mobilization from below can serve as the catalyst for the democratization of global regimes.

The case for global civil society has not been made with the same analytic precision as the arguments for civil society at the domestic level. Nevertheless, many of the same themes can be discerned. The liberal vision of associations as a vehicle for the pursuit of individual life projects and as checks on state power is implicit in much of the writing on global civil society. ${ }^{97}$ And the international aid literature relies heavily on social capital and communitarian theories: today the common wisdom among donor countries and international development agencies is that aid should be given to local associations, not only to governments. The reasons for this policy shift are generally of the social capital and communitarian varieties: by giving such associations responsibility for implementing development projects and undertaking social service functions, international aid will build citizenship skills, improve the capacity for selfgovernment, and strengthen communities. ${ }^{98}$

\footnotetext{
95 See Etzioni, Law in Civil Society, supra note_at 366, 367, 375, 376.

96 See Richard FalK, On Humane Governance 106, 199, 253 (1995); John Keane, Global Civil SOCIETY 8-20 (2003); MARGARET E. KeCK \& Kathryn SiKKINK, ACTIVISTS BEyOND Borders: AdVOCACY NeTWORKS IN INTERNATIONAL POLITICS 10-11 (1998).

${ }_{97}$ See John Keane, Global Civil Society, supra note__ at 169, 202.

${ }^{98}$ See World Bank, 2003 Annual Report, 13, 18, 71; UN Development Programme, Partners in Human Development: UNDP and Civil Society Organizations, 17, 22, 23, available at http://www.undp.org/cso; UN Development Programme, Partners in Human Development: UNDP and Civil Society Organizations, A Policy of Engagement, available at htttp://www.undp.org/cso/policies.html ("Possible entry points for UNDP-CSO collaboration").
} 
Notwithstanding some overlap with the domestic literature, the literature on global governance also reflects a distinct theory of civil society and democracy. According to thinkers like Daniele Archibugi, Richard Falk, David Held, Mary Kaldor, and John Keane, a global society is necessary to curb the forces of global capital and to ensure that political institutions of global governance vindicate the ambitions and desires of ordinary people throughout the world. ${ }^{99}$ In this line of thought, globalization not only creates benefits, but imposes severe hardships, to which heads of state and international bureaucrats in control of international regimes are unable to respond. The elites that negotiate and administer international agreements cannot ensure that the forces of global capital are harnessed to the advantage of ordinary people. For cosmopolitans, it is critical that citizens of one country come to identify with citizens of another country based on their shared, human experiences.

Transnational groups based on rural and urban poverty, the market, and environmental depredation should compete and interact with other transnational groups to influence public decisionmakers in the global polity. Global civil society is the key to creating a truly democratic international order, for only when citizens organize and identify with others in different parts of the world can they can assert control over the forces of global capitalism and the illegal actions of states in the international realm.

Transnational social forces provide the only vehicle for the promotion of the law of humanity, a normative focus that is animated by humane sustainable development for all peoples, North and South, and seeks to structure such commitments by way of human geo-governance .... To suggest the political dynamics associated with these conceptions, I propose the terminology of 'globalization-from-below' to identify these transnational democratic forces, and their implicit dedication to the creation of a global civil society that is an alternative scenario of the future to that of the global political economy being shaped by

\footnotetext{
99 See Daniele Archibugi, Principles of Cosmopolitan Democracy, in RE-IMAGINING POLITICAL COMMUnity: STUdies in COSMOPOLITAN DEMOCRACy 198, 222 (Daniele Archibugi, David Held, \& Martin Köhler, eds., 1998); Commission On Global GovernanCE, Our Global NeighbOurhoOD: The Report of the Commission On Global Governance 56 (Oxford: Oxford University Press, 1995); Richard Falk, Global Civil Society: Perspectives, Initiatives, Movements, 26 Oxford DevelopMENT Studies 99, 100 (1998); Richard FALK, On HumAn GOVERnANCE: TOWARDS A NeW GlObal POLITICS: The World Order Models Project Report of the Global Civilization Initiative, 106 (1995); Keane, Global Civil Society, supra note_2, 173; David Held, Democracy and Globalization, in REImagining POlitical COMMUnity: STUdies In COSMOPOLITAN DeMOCRACy 11, 22-23 (Daniele Archibugi, David Held, \& Martin Köhler, eds., 1998); Mary Kaldor, Global Civil Society, in THE Global Transformations ReAder 559, 560 (David Held \& Anthony McGrew, eds., 2000); P. Wapner, The Normative Promise of Nonstate Actors: A Theoretical Account of Global Civil Society, in Principled World Politics: The Challenge of Normative International Relations 261, 267 (P. Wapner \& L.E. J. Ruiz eds., 2000).
} 
transnational market forces. The hopes of humanity depend, in my view, upon the capacities of globalization- from-below to challenge effectively the prevailing dominance of globalizationfrom-above in a series of key arenas that can be identified in very general terms as the UN (and other international institutions and regimes), the media, the orientation of states. ${ }^{100}$

Cosmopolitans define civil society very differently from liberal, republican, and communitarian thinkers. For cosmopolitans, interest and identity associations are not, in and of themselves, civil society. Global civil society is the global people. This stands in marked contrast with domestic theories. At the domestic level, "civil society" is distinct from "the people": "civil society" refers exclusively to organizations outside the state; "the people" refers to long-standing national identities embodied in national constitutions, electoral politics, and the representative institutions of democracy. Further, cosmopolitans are categorical in excluding large market actors--namely, multinational corporations and organizations representing multinationals--from their definition of civil society. Given that global capital is one of the forces to be curbed by civil society, organizations and individuals that serve the interests of capital cannot be part of civil society.

A global civil society as an integrated public sphere in which national borders disappear and a single people emerges is a very demanding definition. It should not come as any surprise that, in the opinion of most scholars, it does not yet exist. ${ }^{101}$ Thinkers like John Keane, Richard Falk, and Mary Kaldor, dissatisfied with the current state of global capitalism and international regimes, urge social activists to mobilize transnationally and to fight for a more just, peaceful, and environmentally sound world. This prescription echoes those of their republican and communitarian counterparts, who also exhort citizens to organize from below.

In addition, a number of cosmopolitan theorists have called for a directly elected world parliament that would represent global civil society in international lawmaking. They believe that elections and a legislative assembly would ensure that the voice of civil society is heard by the state elites and

\footnotetext{
${ }^{100}$ Richard Falk, The World Order between Inter-State Law and the Law of Humanity: The Role of Civil Society Institutions, in COSMOPOLITAN DEMOCRACY: AN AGENDA FOR A NEW WORLD ORDER, 63, 170-71 (Daniele Archibugi \& David Held eds. 1995) (emphasis added).

${ }^{101}$ See, e.g., Marie-Josée Massicotte, 'Local' Organizing and 'Global' Struggles: Coalition-Building for Social Justice in the Americas, in GLOBAL CIVIL SOCIETY AND ITS Limits 105, 105-06 (Gordon Laxer \& Sandra Halperin eds., 2003); Lisa Sundstrom, Limits to Global Civil Society: Gaps Between Western Donors and Russians NGOs, in GLOBAL CIVIL SOCIETY AND ITS LiMITS 146, 146-47 (Gordon Laxer \& Sandra Halperin eds., 2003). Steve Charnovitz and I have found that civil society in the transatlantic context also comes up short when this demanding definition is used. See Francesca Bignami \& Steve Charnovitz, Transatlantic Civil Society Dialogues, in TransatLantic GovernanCE IN THE GLOBAL ECONOMY 255 (Mark A. Pollack \& Gregory C. Shaffer eds., 2001)
} 
international bureaucrats that at present control international regimes. For instance, Richard Falk and Andrew Strauss have proposed a "Global Peoples Assembly." 102 Yet voluntary associations and intermediate organizations are conspicuously absent from the single institutional reform proposed by cosmopolitans. ${ }^{103}$ While Falk and Strauss argue that citizens and their associations should have the right to lobby the Global Peoples Assembly, they do not recommend a direct role for private organizations in the decisions taken by the Assembly, nor does the logic of representative democracy suggest such a role.

The ambition expressed in the proposals for a world parliament is admirable but, on closer examination, such proposals reveal a fundamental inconsistency. In instituting a world assembly, cosmopolitan thinkers assume into being precisely that which they lament is lacking from world politics: a global civil society or global people. That is, cosmopolitan thinkers assume the existence of a global people that would mobilize during elections, vote, and then follow and monitor the decisions of their global representatives. Yet it is not obvious that simply instituting elections and a world parliament would lead to the formation of such a global consciousness. ${ }^{104}$ The European Parliament is a legislative assembly that operates in what was previously a classic international organization, with powers beyond the wildest dreams of even the most optimistic cosmopolitans. Yet the European public has displayed a stubborn indifference to elections for the European Parliament and the daily activities of their parliamentarians. ${ }^{105}$ Cosmopolitans do not have a clear vision of how

\footnotetext{
102 See Richard Falk \& Andrew Strauss, On the Creation of a Global Peoples Assembly: Legitimacy and the Power of Popular Sovereignty, 36 STAN. J. INT'L L. 191, 193 (2000).

${ }^{103}$ Richard Falk and Andrew Strauss have suggested that, as a first step towards the Global Peoples Assembly, representatives of civil society organizations should constitute the Assembly but that, shortly thereafter, civil society organizations and their representatives should draw electoral districts, decide on a voting system, and hold elections. See Andrew Strauss, Overcoming the Dysfunction of the Bifurcated Global System: The Promise of a Peoples Assembly, in REFRAMING THE InTERnATIONAL: LAW, Culture, Politics 83, 83 (Richard Falk et al. eds., 2002). Expedience, however, is the only justification for giving this task to civil society organizations and it is far from self-evident that, once their representatives had taken their seats in the Global Peoples Assembly, they would be willing to relinquish their seats in favor of elected representations or be able to organize such elections.

${ }^{104}$ Hassan El Menyawi has recently put forward a interesting proposal for multiple assemblies--one for each nation-- that combines global representation with the necessary first step of creating a global people that selects representatives and thus is represented. He propose one general assembly for each nation. Each such assembly would be composed of 191 representatives, which would be elected jointly by the electorates of two different nations: the nation where the general assembly is located and one of the other 190 nations in the world. This process, according to El Menyawi, would foster deliberation across national borders and hence would improve democracy in an interdependent world. See Hassan El Menyawi, Toward Global Democracy: Thoughts in Response to the Rising Tide of Nation-to-Nation Interdependencies, 11 IND. J. GLOBAL LeGAL STUD. 83, 96, 125, 130-31 (2004).

105 See David Judge \& David Earnshaw, The European Parliament 70-76 (2003).
} 
public policy can promote an integrated, global public sphere or how associations outside the state can contribute--and, through public policy initiatives, can be encouraged to contribute--to the creation of such an integrated public sphere.

The arguments and implications of the theories of civil society are summarized below.

Table 1: Theories of Civil Society: Justifications, Definitions, and Policy Prescriptions

\begin{tabular}{|c|c|c|c|}
\hline & Justification & Definition & Policy prescriptions \\
\hline Liberal & $\begin{array}{l}\text { Allows individuals to } \\
\text { realize diverse life } \\
\text { projects and checks } \\
\text { government power }\end{array}$ & All associations & Liberal rights \\
\hline $\begin{array}{l}\text { Republican } \\
\text { - } \quad \text { Robert } \\
\text { Putnam } \\
\text { - } \quad \text { Theda } \\
\text { Skocpol }\end{array}$ & $\begin{array}{ll}\text { - } & \text { Build social } \\
\text { capital among } \\
\text { citizens }\end{array}$ & $\begin{array}{l}\text { All associations } \\
\text { except } \\
\text { corporations, } \\
\text { corporate } \\
\text { lobbies, and } \\
\text { professionalized } \\
\text { pressure groups } \\
\text { Large, } \\
\text { nationwide } \\
\text { federations } \\
\text { engaged in } \\
\text { national political } \\
\text { debates }\end{array}$ & $\begin{array}{l}\text { Tax code reform to } \\
\text { encourage private } \\
\text { donations, urban } \\
\text { planning to reduce } \\
\text { sprawl, employment } \\
\text { regulation to allow } \\
\text { workers to spend more } \\
\text { time with family and } \\
\text { participate in } \\
\text { community } \\
\text { organizations, public } \\
\text { investment in } \\
\text { education, } \\
\text { opportunities for } \\
\text { participation in local } \\
\text { government, transfer of } \\
\text { public powers and tax } \\
\text { dollars to associations } \\
\text { Provide incentives for } \\
\text { associations to engage } \\
\text { in partisan politics, } \\
\text { afford large } \\
\text { membership } \\
\text { associations a special } \\
\text { role in Congressional } \\
\text { deliberations }\end{array}$ \\
\hline Communitarian & $\begin{array}{l}\text { Mores inculcated by } \\
\text { civil society essential } \\
\text { to self-identity and } \\
\text { good government }\end{array}$ & $\begin{array}{l}\text { Family, churches, } \\
\text { local associations }\end{array}$ & $\begin{array}{l}\text { Reduce size of state, transfer } \\
\text { responsibility for social } \\
\text { services from federal } \\
\text { government to local } \\
\text { charities and churches }\end{array}$ \\
\hline
\end{tabular}




\begin{tabular}{|l|l|l|l|}
\hline Cosmopolitan & $\begin{array}{l}\text { Assert popular } \\
\text { control over forces of } \\
\text { globalization }\end{array}$ & $\begin{array}{l}\text { Integrated, global } \\
\text { public sphere, i.e., } \\
\text { "the global people," } \\
\text { excluding capital }\end{array}$ & Global Peoples Assembly \\
\hline
\end{tabular}

\section{The Implications of Civil Society Theory for Global Governance}

What do these different theories of civil society have to say about the institutional reform of international organizations such as the World Bank, the World Trade Organization, and the European Union? First, the liberal understanding of civil society has considerable merit and should be embraced by global policymakers. Contemporary democracy is inconceivable without a vibrant public sphere in which citizens and their associations have the right to criticize government actors. Of course, comparative constitutional law demonstrates that contemporary democracies part ways over where the rights to free expression and association end and the rights to privacy and against discrimination begin. However, it is not necessary to dwell here on any of these thorny debates of constitutional law. It is enough to observe that citizens and their organizations must enjoy a core of speech, association, and other liberal rights if the different sites of global governance are to be democratic.

The agreement among the liberal, republican, and communitarian positions on the importance of such rights reveals their foundational quality. Rights of speech and association can co-exist quite happily with republican tax code reform, investment in public education, opportunities for participation in local and national government, and the transfer of tax dollars and public powers to non-state associations. There is no inconsistency in arguing that the National Organization of Women and the National Rifle Association should be able to march and petition government officials and benefit from exemptions under the tax code. Liberal and communitarian models of civil society are also compatible: for community organizations to flourish, they must benefit from freedom of association and expression, including freedom of religion. This is not to deny that these two theories of state and society can come into conflict. The difficulty comes from the invocation of rights such as freedom of expression in support of certain world views that undermine the substantive values at the core of the communitarian associations of family, church, and neighborhood. ${ }^{106}$

\footnotetext{
${ }^{106}$ Benedict Kingsbury has argued that, in the international sphere, the dominant liberal model of speech and associationalism linked to the First Amendment to the U.S Constitution is at odds with the articulation of rights and demands by indigenous peoples and other ascriptive groups, groups with considerable affinities to communitarian notions of civil society. See Benedict Kingsbury, First Amendment Liberalism as Global Legal Architecture: Ascriptive Groups and the Problems of the Liberal NGO Model of International Civil Society, 3 CHI. J. INT'L L. 183 (2002). Nevertheless, as Kingsbury himself observes, nothing intrinsic to the First Amendment leads to the denigration or exclusion of indigenous peoples in the international realm, rather it is the political theory of liberalism more generally speaking that produces this result. In Kingsbury's words: "A liberal commitment to
} 
Communitarians like Amitai Etzioni, however, argue that liberal rights can be reconciled with communitarian moral responsibilities. ${ }^{107}$ In global regimes, regimes which, by definition, include many nations and traditions, cooperation is possible only if local identities and values give way to liberal rights and tolerance when the two come into irreconcilable conflict.

Liberal theory's policy prescriptions are largely in place in the global realm and are firmly established in the European Union. The Covenant on Civil and Political Rights, which contain provisions on freedom of opinion and expression, and freedom of assembly and association, has been ratified by over 130 countries. Together with the Universal Declaration of Human Rights, the Covenant serves as a source of law binding upon international organizations when they deal directly with citizens and associations. ${ }^{108}$ In the European Union, the Court of Justice has guaranteed the right to freedom of expression and association since the 1980s, and these rights have been codified in the European Charter of Fundamental Rights. ${ }^{109}$ Furthermore, one of the prerequisites of the right to oppose global policies--the right to know what government has decided, i.e. transparency--is becoming standard practice in global regimes. ${ }^{110}$

Transparency, as used here, is different from attending multilateral committee meetings, submitting policy statements, and filing amicus briefs: it is the duty of global institutions to broadcast their decisions at the time they are made in language accessible to the ordinary citizens so that citizens and their associations can debate, criticize, and hold public officials to account.

Even though liberal theory is widely accepted, its prescriptions are not always heeded by international policymakers. Organizations like the World Bank and the WTO have real incentives to avoid their constitutional duties in the interests of speedy policymaking. It is tempting for statesmen and bureaucrats

voluntarism and individual choice underpins a model of international civil society in which voluntary NGOs (or corporations) are the paradigmatic actors.... While liberal political theory has embraced certain forms of NGOs (including civic associations and, with palpable misgivings, corporations and industry associations) in which entry and exit are voluntary, it has hesitated to embrace ascriptive intermediate groups." Id. at 187-88.

107 See, e.g., Amitai Etzioni, The New Golden Rule: Community And Morality in a Democratic SOCIETY (1996); AMITAi ETZIONI, THE SPIRIT OF COMMUNITY: RIGHTS, RESPONSIBILITIES, AND THE COMMUNITARIAN AGENDA 4-5 (1993).

108 Universal Declaration of Human Rights 71, arts. 19 \& 20, U.N. Doc. A/810 (Dec. 10, 1948); International Covenant on Civil and Political Rights, arts. 19 \& 21, opened for signature Dec. 19, 1966, 999 U.N.T.S. 171, 6 I.L.M. 368 (entered into force Mar. 23, 1976); see IAN BROWNLIE, PRINCIPLES OF Public InTERnATIONAL LAW 575, 576 (5 $5^{\text {th }}$ ed. 1998).

${ }^{109}$ Case 100/88, Oyowe and Traore v. Commission, 1989 E.C.R. 4285 (freedom of expression); Case C-274/99P, Connolly v. Commission, 2001 E.C.R. I-1611 (freedom of expression); Case C-415/93, Union Royal Belge des Sociétés de Football v. Bosman, 1995 E.C.R. I-4921, para. 79 (freedom of association); European Charter of Fundamental Rights, art. 11 (freedom of expression) \& art. 12 (freedom of assembly).

${ }^{110}$ See supra text accompanying nn. (describing transparency measures in World Bank and WTO); Bignami, Creating European Rights, supra note__(describing transparency in the EU). 
in international organizations to turn a blind eye to state practices that render debate and opposition to international economic policies impossible because such statesmen and bureaucrats have an obvious interest in pushing their policies through at the domestic level. The same incentives threaten freedom of expression at the global level: vigorous protest on the streets of Seattle, Doha, and Cancun; on the pages of newspapers; and on the web can undermine public support for international economic policies. Therefore, when given the choice, politicians and bureaucrats prefer less, not more, speech. Furthermore, unlike the European Union, members of international economic organizations are not all democracies, so the institutions of member countries cannot be expected to impose democracy and constitutional rights from below as has been the European experience. And, again unlike the European Union, international economic organizations do not have independent courts to which individuals can appeal to fight for their freedoms of expression and association. In sum, while the liberal rights necessary for a vibrant civil society might figure prominently in the rhetoric and written law of the international realm, the realities of international organizations suggest that such rights are fragile and extreme vigilance is necessary to preserve them.

The republican and communitarian theories of civil society similarly share one, important point of convergence: in neither do corporate actors or professionalized pressure groups that lack substantial memberships count as civil society. In other words, political philosophy offers no support for extending policies targeted at civil society to corporations, corporate lobbies, and public interest advocacy groups without a membership base. While the indifference to profit-driven actors is not particularly surprising, the absence of any analytical or empirical basis for institutional measures targeted at small groups of social activists goes against common wisdom. This is because many of the most vociferous advocates of civil society in the global realm are small, social justice NGOs; yet in the civil society lexicon, they fall into the pressure group category, not the civil society one.

Nevertheless activists without a rank-and-file might be able to make claims on the institutions of global governance on other grounds. For instance, some groups can argue that they promote substantive ends that have been unfairly excluded from global politics and that therefore their voices should count more. Or, they might claim that small networks of activists help build an integrated, global public sphere and that public resources and powers should be allocated to such networks to support their initiatives. Yet no political philosophy, not even cosmopolitan theory, articulates these hypotheses. The case for networks and associations of activists that focus on promoting their public interest agendas rather than building broad-based, grassroots constituencies has not been made.

Although republican and communitarians thinkers can agree on which actors to exclude from civil society, their affirmative definitions of civil society 
and their related policy prescriptions differ considerably. Social capital and communitarian theory part ways with the national republican view. Both Robert Putnam and Amitai Etzioni stress local forms of associationalism while Theda Skocpol argues that large, diverse membership organizations are the backbone of American democracy. ${ }^{111}$ International organizations have already taken on board, grosso modo, the prescriptions of the social capital and communitarian lines of analysis, especially institutions like the World Bank whose policies are targeted at the local or regional levels and whose mission is development. By involving local NGOs in loan management and giving small grants to NGOs, the World Bank and other international development organizations are clearly building upon the insights of thinkers like Putnam. Funding local associations, allowing them to participate in international aid decisions, and giving them responsibility for putting the aid to good use are policy initiatives that follow closely the prescriptions of the social capital and communitarian models. International organizations and the government recipients of development aid could certainly do better, as suggested by some of the criticism canvassed above. ${ }^{112}$ Nonetheless, the institutions of global governance are headed in the right direction, and the social capital and communitarian ideas of civil society should serve as an impetus for further institutional reform.

And what of Skocpol's analysis? It does not appear that global policymakers have taken notice of Skocpol's theory of civil society. Yet she focuses on a historical phenomenon - the development of a national economy and polity in the United States - that bears some resemblance to today's accumulation of economic and political power in new sites of global governance. Skocpol chronicles the simultaneous rise of a national government and national voluntary associations in nineteenth and early twentieth-century America. She notes the vital role of such associations in enabling ordinary citizens to participate in democratic politics:

Directly, therefore, as well as in a number of indirect ways, America's traditional voluntary membership federations fostered

\footnotetext{
${ }^{111}$ I do not address an additional issue that divides civil society thinkers. Should resources be redistributed to ensure that all citizens have an equal opportunity to form and participate in voluntary associations? This is a cross-cutting issue that is tied to the larger question of social justice, a question which divides thinkers who otherwise join forces in articulating a common view of the role of associations in democratic life. For instance, while Michael Walzer would use state power to redistribute resources and promote certain associations, others in the liberal camp, more suspicious of the state after the experience with totalitarian regimes in Eastern and Central Europe, would not. Compare Walzer, The Concept of Civil Society, supra note_at 26 with Nardin, Private and Public Roles in Civil Society, supra note_at 30-32. Thinkers who advocate local associationalism are similarly divided. While Putnam advocates transfers of resources from wealthy to poor communities, many conservative communitarians do not. See PutnAM, Bowling AlOnE, supra note_ at 413. The issue of social justice affects almost every aspect of political life and therefore goes beyond the scope of this narrowly focused discussion of civil society.

112 See supra text accompanying nn.
} 
active citizenship and made a difference in politics and governance. Federations were especially vital in building an American democracy in which ordinary people could participate, gain skills, and forge recurrent ties to one another--not just locally but also across communities, states, and regions of a vast and expanding nation. ... Over the long run of U.S. history, voluntary membership federations have both complemented and rivaled political parties in setting the course of politics and government. By coordinating and inspiring so many people across the myriad districts that elect representatives to U.S., state, and national legislatures, voluntary federations have been able to exert democratic leverage. Federations combine state and national reach with local presence, the best way to influence U.S. elected officials. ${ }^{113}$

This explanation of the importance of nationwide federations is instructive for cosmopolitans. As mentioned earlier, cosmopolitans oppose the concentration of economic and political power in the hands of elites who run multinational corporations and set the course of international economic organizations. But cosmopolitans also recognize that the global people cannot exercise their democratic will because citizens are still separated by national borders. The voluminous literature on the democratic deficit in the European Union repeats this complaint. Without a European-wide political consciousness and citizens that engage on the everyday questions settled in Brussels, Europe cannot be truly democratic. One remedy to the cosmopolitan and European dilemma, suggested by Skocpol's analysis, is the formation of large membership organizations that span entire regions or, indeed, the globe. Far-flung federations that routinely bring together their national members and associations might enable citizens and activists throughout Europe--or even the world--to mobilize across state lines, just as nationwide organizations with local chapters did in early twentieth century America. Transnational associations might be one means of overcoming the tension between central political and economic power and local democracy.

What policy measures would encourage the creation of such membership organizations? Some of the same initiatives undertaken by international institutions to promote local civil society could be targeted also at transnational civil society. Direct funding of citizen associations could go to organizations that meet certain threshold requirements of numbers and geographic distribution of membership. Moreover, in response to Skocpol's call to politics, such direct funding should go not only to associations devoted to economic development or social welfare, but also to those engaged in partisan, political activities. Finally,

113 SKOCPOL, DIMINISHED DEMOCRACY, supra note__ at 124. 
opportunities for participation in the policymaking of international organizations could be reserved for such transnational associations. This would not be participation in policymaking with mainly local effects, such as the implementation and management of World Bank project loans, but rather participation in policymaking of concern to multiple countries or entire regions of the world. Allowing the participation of transnational associations would mirror Skocpol's recommendation that American membership organizations of national scope be given special access to Congressional deliberations.

Privileging transnational associations in global policymaking is not a novel idea. It already occurs in the United Nations system and the European Union. In the United Nations, large, international NGOs whose policy agendas cover multiple issues qualify for general consultative status before the Economic and Social Council. ${ }^{114}$ General consultative status entitles NGOs to receive provisional agendas, place items on the agenda, sit as observers at public meetings, submit brief written statements, consult with members of the Secretariat, and request to make oral presentations at public meetings. In the European Union, the Commission is required to consult advisory committees in areas such as agriculture, the environment, and consumer policy. ${ }^{115}$ The composition of such committees is generally weighted towards pan-European federations of farmers, environmental groups and consumer organizations, not purely national or local associations. Building on this precedent, international organizations should adopt more extensive funding and participation measures to encourage the formation of regional and global associations and transnational solidarities.

In making these reforms, policymakers should not lose sight of the local. It is important to remember communitarian Michael Sandel's admonition that in a globalizing world, local community will and must continue to shape selfidentities, inculcate moral virtues and foster social learning:

It is difficult to imagine a [cosmopolitan] world in which persons were so virtuous that they had no friends, only a universal disposition to friendliness. The problem is not simply that such a world would be difficult to bring about but that it would be difficult to recognize as a human world. The love of humanity is a noble sentiment, but most of the time we live our lives by smaller solidarities. This may reflect certain limits to the bounds of moral sympathy. More important, it reflects the fact that we learn to

\footnotetext{
114 See United Nations Non-Governmental Liaison Service (NGLS), The NGLS Handbook OF UN

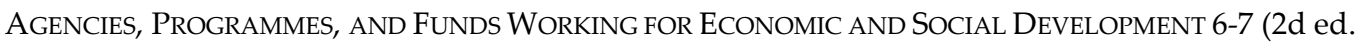
1997); Peter Willetts, The Rules of the Game: The United Nations and Civil Society, in WHOSE WORLD IS IT ANYWAYS 247-82 (John W. Foster, Anita Anand, Jing de la Rosa eds. 1999).

${ }^{115}$ See Bignami, Creating European Rights, supra note_ at _.
} 
love humanity not in general but through its particular expressions.

But even though a global neighborhood lacks the intimacy of the local, the current historical circumstances of globalization and the vital role of cosmopolitan solidarities in transforming international regimes into transnational democracies, cannot be ignored.

The different theories of civil society contain important lessons for the organization of global political life. Yet, in the final analysis, the philosophers and activists of civil society are talking past one another. Philosophers of civil society focus on the value of associational life free of the state. The theories explain the importance of voluntary associations for political life in a democracy, exhort citizens to join such associations, and recommend government measures designed to promote their preferred forms of voluntary associations. However, they do not develop a model of how civil society should shape democratic decisionmaking nor do they articulate a series of institutional reforms that would enact that model. Should associations demonstrate and write press articles, run election campaigns, lobby legislators, sit on government committees, comment on proposals for legislative and administrative action, or sue government officials in court? The political philosophy does not address this series of questions. Yet this is what the political debate in the different systems of global governance is all about: how should associations outside the state, acting in an integrated, cosmopolitan political space, inform public decisionmaking? For guidance we must look elsewhere.

\section{The Comparative Law of Democracy}

For inspiration on civil society's place in democratic institutions, we should look beyond the political philosophy to the comparative law of democracies. ${ }^{116}$ The constitutions of contemporary democracies follow one of

\footnotetext{
${ }^{116}$ Even when the question is reframed as "How do interest and identity groups fit with the procedural requirements of democracy?" political philosophy is largely unhelpful. On this issue, contemporary thinkers take opposite views. Civic republicans and deliberative democrats oppose interest groups and identity politics in favor of deliberation among all citizens based on broadly shared principles. According to thinkers such as Cass Sunstein, Amy Gutmann, and Dennis Thompson, public decisions should be made through appeal to commonly accepted reasons, not through bargains among competing interests or conflicting identities. See AMY GUTMANN \& DENNIS THOMPSON, Why Deliberative DEMOCRACY? 13-36 (2004). In their view, enlightened majority rule is guaranteed through the collective process of defining and redefining a shared set of values and morals. By contrast, in Schumpeter's model of democracy, politicians vie for the support of voters and interest groups play an important, benign role in serving as intermediaries between politicians and voters. Interest groups facilitate the competitive democratic process. See DAVID HELD, MODELS OF DEMOCRACY 185-91 (1996). My resort to the comparative law of democracy is, in part, a product of the "conventionalist" or "hermeneutic" turn in contemporary philosophy. See MiCHAEL J. SANDEL, LibERALISM AND THE LIMITS OF JUSTICE (2d ed. 1998); RAWLS, POlitiCAL LibERALISM, supra note_; RICHARD RORTY, CONTINGENCY, IRONY, AND SOLIDARITY (1989). This movement away from
} 
three patterns: pluralism, corporatism, and republicanism. ${ }^{117}$ In pluralism, multiple, competing interest groups have numerous opportunities to influence policymaking, irrespective of their size or aims, through the legislature, the bureaucracy, and the courts. In corporatism, certain intermediate organizations are allowed to influence policymaking because their membership figures or their objectives are believed to warrant giving them a special role, alongside legislators, bureaucrats, and judges, in making public decisions. ${ }^{118}$ In republicanism, citizen associations enable individuals to engage in the public life of the nation through debate and protest, but those associations are not allowed to take part directly in making public decisions.

International policymakers should appreciate that even though their historical circumstances are novel, they do not act in a political or institutional void in deciding on associational participation in global governance. Their predilections for interest accommodation in the global realm are shaped by their experiences in their distinct pluralist, corporatist, and republican democracies. Even more important than self-awareness of national bias is what policymakers

deontological, deductive truths and towards more historically and culturally situated moralities came as a reaction to Rawls's Theory of Justice. By emphasizing the diversity of national experiences with liberal democracy, yet only considering liberal societies, I strike an uneasy balance between these two positions. But it is no more unstable than the balance struck in many of today's great works of political theory. See, e.g., JOHN TOMASI, LIBERALISM BEYOND JUSTICE: CITIZENS, SOCIETY AND THE BOUNDARIES OF POLITICAL THEORY (2001) (criticizing Rawls's attempt to accommodate his conventionalist critics in Political Liberalism). Moreover, comparative law-as compared to political theory--has the great advantage of concreteness; the level of analysis is specific enough to assist international policymakers with the details of institutional design.

117 See, e.g., Paul S. Adams, Is There a New Century of Corporatism? in NEW DIRECTIONS IN Comparative Politics 17, 28 (Howard Wiarda ed., 3d ed. 2002); DAvid Held, Models of DEMOCRACY 197-232 (1996); Arendt Lijphart, Patterns of Democracy: Government Forms and Performance, in THIRTY-Six COUNTRIES 171 (1999); YVES MÉNY, GOVERNMENT AND POLITICS IN WESTERN EUROPE 151-56 (Janet Lloyd trans. 2d ed. 1993); Philippe C. Schmitter, Still the Century of Corporatism?, 36 ReV. OF POL. 85, 93-94 (1974); GRAHAM K. WiLsON, InTEREST GROUPS (1990). Most political scientists distinguish only between corporatist and pluralist systems. However, some go further and differentiate between systems in which interest groups are assured access to official decisionmaking (pluralism or corporatism) and systems in which interest groups are heterogeneous and competitive but generally are not allowed to influence government policymaking (called here "republicanism"). See Vivien A. Schmidt, Europeanization of National Democracies: The Differential Impact on Simple and Compound Polities, 13 POLITIQUE EUROPÉENNE 113, 115-116 (distinguishing between "compound" and "simple" polities); POLICY STYLES IN WESTERN EUROPE (Jeremy Richardson ed., 1982) (characterizing French government as closed to interests and ready to impose policy choices and German government as open to interests and eager to obtain social consensus).

118 While most corporatist theorists focus on intermediate associations of capital and labor, the corporatist relationship between state and society extends to the associations that have become salient in the era of what Ronald Inglehart calls "post-material" values: environmental protection groups, consumer groups, and identity groups based on national origin, sex, and race. See generally

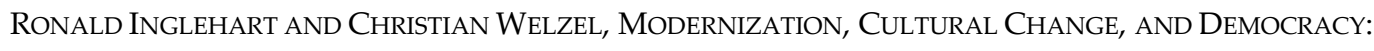
THE HuMAN DEVELOPMENT SEQUENCE (forthcoming). 
can learn from the different national experiences with interest and identity groups in public life.

The following sections elaborate on pluralism, corporatism, and republicanism by analyzing the constitutions, laws, and regulations of three democracies that typify the distinct patterns of interest participation: the United States, Germany, and France. The ambition of this Article is to speak to policymakers, hence the need to enter into the law to understand the implications of the different models for the institutions of global governance. In exploring these national legal systems, the reader should bear in mind that even within a system, the law of interest participation differs among policy areas and often departs from the ideal type. Moreover, my claim is not that there is only one law of pluralist democracy, one law of corporatist democracy, and one law of republican democracy. The world's political systems undoubtedly contain many others laws and models of democracy. But three is a good start in bringing to light the different possibilities of associational participation in the institutions of global governance.

The following discussion of the public law of interest accommodation also examines the popular theories of democracy behind the law. Specific theories of democracy informed the U.S., German, and French constitutions at their beginnings and related, evolving popular ideas of democracy continue to sustain these constitutions. In other words, public law reflects culturally specific norms about how public affairs should be conducted; public law is also grounded on certain beliefs as to the consequences for collective prosperity and individual well-being of different institutional arrangements, including those for associational participation. ${ }^{119}$ That the comparative law of interest accommodation embodies culturally specific norms and beliefs suggests that the differences must be taken seriously indeed. That certain beliefs, although perfectly credible at home, cannot survive the realities of the global realm while others can, shows that a principled choice among the competing theories can be made for international organizations.

\section{Pluralist Democracy}

The United States is the only clear example of pluralist democracy. ${ }^{120}$ The Constitution establishes a fragmented system of lawmaking which guarantees

\footnotetext{
119 See PAul Pierson, Politics in Time: History, Institutions, And SOCiAl ANAlysis 38-40 (2004) (analyzing relationship between institutions and preferences, identities, and ideologies); Schmidt, supra note_ at 126-131 (discussing relationship between institutions and ideas of democracy). ${ }^{120}$ Although many other western democracies have a multiplicity of interest groups that are not organized into peak associations and that compete among one another for influence, their political systems do not afford the competing interest groups the same opportunities to influence policymaking. Among the democracies covered in Arendt Lijphart's overview of political systems around the world, it appears that Costa Rica and Columbia qualify as pluralist: they both score relatively high on the interest group measure (2.50), they both are presidential systems (which is
} 
interest groups of all kinds numerous opportunities to influence policymaking. ${ }^{121}$ Legislative power is shared among the Senate, the House of Representative, and the President, each of which is elected by different constituencies and serves different terms. In the lawmaking process, therefore, interest groups have multiple opportunities to shape outcomes. ${ }^{122}$

When legislation is sent to the bureaucracy for implementation, the law continues to afford interest groups a central role in the policymaking process. In the American presidential system of government, administrators are accountable to both the President and legislators on Congressional oversight committees and, through them, to multiple interest groups. ${ }^{123}$ Furthermore, the public has a right to receive advance notice of rules, give their view on such rules, and receive a detailed response to their objections from the administration. ${ }^{124}$ Because any individual or interest association may go to court to enforce the right to notice, comment, and a detailed explanation of the rule's basis and purpose, the bureaucracy heeds the views of all associations, regardless of the association's purposes or membership numbers. Moreover, courts require that administrators apply what Thomas McGarity calls "comprehensive analytical rationality" to regulatory problems: administrators must conduct a thorough and definitive assessment of the costs and benefits of all possible regulatory options before choosing the one that best fulfills the statutory mandate, even though such an assessment is sometimes impossible in the face of scientific and political realities. ${ }^{125}$ Comprehensive analytic rationality guarantees that the bureaucrats

related to high interest group access because of the division of power between the presidency and the parliament), and they both score low on the executive dominance measure (which is related to the presidential-parliamentary distinction). See Lijphart, supra note_, at 177, 119, 138.

121 See George Tsebelis, Veto Players: How Political Institutions Work 78-79, 139-43 (2002) (describing fragmentation caused by American presidential and federalist system of government). For the sake of brevity, this Article does not cover two other dimensions of political organization that can contribute to more or less interest group access to government decisions: federalism and two-party vs. multi-party systems. Id. at 105, 135.

${ }^{122}$ It appears that the relationship between American political parties and interest groups is very similar to the relationship between American lawmaking institutions and interest groups. One recent study found that American political parties, in contrast with political parties in other democracies, can often function as amalgams of interest groups rather than across-the-board vote maximizers. See Clive S. Thomas, Toward a Systematic Understanding of Party-Group Relations in Liberal Democracies, in POLITICAL PARTIES AND INTEREST GROUPS 286-88 (Clive S. Thomas ed., 2001).

${ }^{123}$ See Robert D. COOTER, The Strategic Constitution 158 (describing system of "multiple principals" under U.S. Constitution); Lijphart, Patterns of Democracy, supra note__ at 117 (on differences between parliamentary and presidential systems of government); JAMES Q. WILSON, BUREAUCRACY 257-58 (describing competition between President and Congress for control of administration).

${ }^{124}$ See 5 U.S.C. $§ 553(\mathrm{c})$ (setting down requirements of notice and comment rulemaking).

125 See Thomas O. McGarity, The Courts and the Ossification of Rulemaking: A Response to Professor Seidenfeld, 75 Tex. L. Rev. 525, 531 (1997); Thomas O. McGarity, Public Participation in Risk Regulation, 1 RISK: IsSUES HEALTH \& SAFETY 103, 112 (1990). 
will take seriously any objections made by the parties to the rulemaking proceeding--including interest groups.

American law rarely entrusts private associations with public authority. Interests and the associations through which they are expressed are considered too partial and self-regarding to be able to handle matters of public concern. Numerous industry associations set product and processing standards, but they generally compete with other industry associations--they do not set "the" standard for all the United States. ${ }^{126}$ Unlike other countries, private associations are not empowered by statute or regulation to set standards for the entire industry. ${ }^{127}$ State governments allow organizations of professionals such as lawyers, architects, and engineers to set rules of conduct for their members and police compliance with those rules. This regulatory practice, however, does not extend beyond professional services to other sectors of the economy. Thus, local chambers of commerce represent the interests of member firms and tradesmen but do not assist the state in regulating their members, in contrast with France, Germany, and Italy where chambers of commerce are entrusted with public functions. ${ }^{128}$

Lastly, the courts are open to all individuals and interest groups to challenge statutes as unconstitutional, to complain that agency action violates principles of administrative law, and to enforce regulatory statutes against private parties when administrative agencies fail to take the lead. ${ }^{129}$ Although legal doctrines such as standing, reviewability, and ripeness are designed to preserve legislative and administrative discretion and to limit the litigation burden on the courts, the reach of such doctrines is very limited compared to

\footnotetext{
126 See Walter Mattli \& Tim Büthe, Setting International Standards: Technological Rationality or Primacy of Power?, 56 WORLD POL. 1, 23-25 (2003).

127 See A.L.A. Schechter Poultry Corp. v. United States, 295 U.S. 495 (1935) (striking National Industrial Recovery Act as unconstitutional delegation of power to the President, based in part on de facto delegation of power to industry associations to set codes of fair competition). But see Jody Freeman, The Contracting State, 28 FLA. ST. U. L. REV. 155, 159 (2000) (discussing new practice of negotiated rulemaking, in which "stakeholders" given decisive role); Industrial Union Department, AFL-CIO v. American Petroleum Industry, 448 U.S. 607, 656 (1980) (discussing OSHA's reliance on standards of private standard-setting bodies in promulgating government standards); Federal Trade Commission, 90 ${ }^{\text {th }}$ Anniversary Symposium 6 (Sept. 22-23, 2004), available at http://www.ftc.gov/ftc/history/90thAnniv_Program.pdf (discussing "trade practice conference" procedure in which industry members would vote on rules then considered by the Commission and, if approved, violation of such rules would constitute "unfair method of competition" under Federal Trade Commission Act).

128 See Mény, supra note__ at 146.

129 See Richard Stewart, The Reformation of American Administrative Law, 88 HARV. L. REV. 1669, 1721 (1975) (analyzing expansion of standing to challenge administrative action in 1960s and 1970s); Richard Stewart \& Cass Sunstein, Public Programs and Private Rights, 95 HARV. L. Rev. 1193 (1982) (analyzing more liberal approach to infering private causes of action to enforce public regulatory statutes).
} 
other legal systems. ${ }^{130}$ To take the doctrine of standing in the administrative context, litigants must overcome two hurdles before a court will entertain their objections to administrative determinations. Litigants must satisfy the constitutional three-prong test of injury, a causal connection between the alleged injury and the administrative determination, and the possibility of redress through judicial intervention; and litigants must show that they come "arguably" within the "zone of injury" that the drafters of the enabling statute intended to protect. But notice that the doctrine does not set the bar very high. As long as an individual can prove an economic, environmental, or, in some instances, aesthetic interest, that is remotely connected to the public policy considerations underpinning the statute, she may challenge the administrative determination.

What are the preferences for public life and the beliefs about the institutions of interest accommodation that underpin American constitutional and administrative law? In pluralist democracy, particular interests and identities are legitimate. ${ }^{131}$ In other words, citizens wish to express themselves in public life through associations that attend to the specific and highly fragmented interests and experiences of economics, region, sex, race, age, and so on, and they believe that public life can prosper through this form of interest politics. Engagement in public life based on particularistic group affiliations is the premise of the political system. Yet, at the same time, the role of interest groups in exercising public authority is more limited than elsewhere. That is because associations based on interest are believed to function simply as conduits through which individual citizens express their differences and inform government decisionmaking. Interest associations do not themselves shape and express broader public identities, commanding the loyalties of their members just like nations command the loyalties of their citizens.

The pluralist understanding of interest is rooted in Madison's political philosophy. Madison believed that passion, self-interest, and faction--impulses hostile to individual rights and the welfare of the nation as a whole--were inevitable among citizens and their elected representatives. A republican system of government would be viable in a country the size of the United States only because in such a vast territory a great number of interests would compete against and check one another in public life. The academic study of American politics after World War II drew on the Madisonian idea of interests as central to public decisionmaking. Not only did Robert Dahl and David Truman observe

\footnotetext{
${ }^{130}$ See John Ferejohn \& Pasquale Pasquino, Constitutional Adjudication: Lessons from Europe, 82 TEX. L. REv. 1671 (2004) (describing different types of constitutional courts and more restricted access in the French and Italian models).

131 See, e.g., Donald P. Kommers, Comments on Part 1, in GERMANY AND ITs BASIC LAW 207, 209 (Paul Kirchof \& Donald P. Kommers eds., 1993) (contrasting "theory of group conflict that undergirds the American perspective on political representation" with the German idea of "popular democracy" and the "strong anti-interest group orientation that informs this [German] jurisprudence").
} 
the role of competing organized interests in persuading government officials to allocate resources and enact laws and regulations, they also condoned the role of interests in American public life. ${ }^{132}$ As long as the rules of the game--the institutions that decided which interests would prevail at any given point in time--enjoyed public consensus and as long as no element of society went unrepresented in the interest group fray, the system would flourish. According to Dahl and Truman, politics would be both stable and fair: no single group would be able to secure control over government and use that control to change the rules to its advantage, excluding other groups.

The normative vision was explicitly questioned by subsequent generations. Congress and administrative agencies were being "captured " by "special interests" rather than representing all interests fairly and neutrally. ${ }^{133}$ But the critique operated from a normative frame of reference in which interest still drove politics, just a more representative, pluralist set of interests. For citizens in the corporatist and republican traditions explored in the following pages, the pluralist understanding of how democracy should be organized is literally and figuratively foreign. Yet this category of thought--groups based on interest and identity--dominates empirical investigations and theoretical analyses of American politics.

Public complacency in the face of pluralist interest group politics is related to a corresponding distrust of elected officials and government bureaucrats. The Constitution splits and shares legislative and administrative powers between the House of Representatives, the Senate, and the President because of the Founders' misgivings as to government by elected officials, misgivings which today extend to the bureaucrats of the administrative state. In the view of the Founders, citizens and their representatives were not inclined toward public virtue, in marked contrast with the republican tradition of Machiavelli, Rousseau, and Harrington. Thus, they believed it necessary to design an unconventional system of separation of powers. Legislative and executive powers were not allocated to different branches, but rather they were spread across both the legislative and executive branches so that one set of officials could check the other. ${ }^{134}$ This checking and balancing by government

\footnotetext{
132 See Robert A. Dahl, Polyarchy: Participation and Opposition (1971); David B. Truman, The GOVERNMENTAL PROCESS (1961).

133 See, e.g., MANCUr Olson, The Logic of Collective Action (1965) (arguing that small groups have an easier time organizing to influence the political process); Peter H. Schuck, Against (And For) Madison: An essay in Praise of Factions, 15 YALE L. \& POL'Y REV. 553 (discussing the phenomenon of capture).

134 See Held, Models of Democracy, supra note_at 89-94; James Madison, Federalist No. 10, in THE FEDERAlist PAPERS 160 (Johns Hopkins University Press 1981) (1787); HANNA FenICHEL PitKIN, THE CONCEPT OF REPRESENTATION 190-98 (1967); POCOCK, THE MACHIAVELliAn MOMENT, supra note_at 513-25 (contrasting the American Constitution with the republican tradition of Machiavelli and the English Civil War and Augustan period); GORDON S. WOOD, THE CREATION OF THE AMERICAN
} 
officials that represent different constituencies was caused by the Madisonian perception of narrow interest rather than republican virtue as the motivating force in democratic politics; today, the system of checks and balance is itself a cause of the omnipresence of interest associations in American political life.

Distrust of public officials, in turn, is associated with limited government-together with the preferences and beliefs that sustain a system of limited government.

In the system that Madison envisages, the danger is action and the safeguard is stalemate, or, as he would have it, balance. Factious interests are to be "broken," "controlled," and "balanced" against each other to produce "stability."135

Interest groups enjoy multiple opportunities to block and stall government action. A government decision like the requirement that a coal-burning power plant be fitted with a scrubber represents a number of lost battles: the energy industry unsuccessfully lobbied members of the Senate, the House, and the President's administration, failed to persuade the civil servants in the Environmental Protection Agency to craft a favorable implementing rule, and lost in court. Because of the numerous opportunities for interest groups of all types to participate directly in public decisionmaking, they can check and constrain the exercise of public power. Interest group pluralism is part of, and contributes to, a culture of democracy in which limited government is thought to be the wisest system of government.

\section{Corporatist Democracy}

Germany is a classic corporatist democracy. ${ }^{136}$ The Basic Law establishes a parliamentary system of government, meaning that the winner of elections to the parliament (Bundestag) selects the head of the executive branch (Chancellor and cabinet). ${ }^{137}$ The Basic Law follows Montesquieu's classic scheme in dividing legislative and executive power between the parliament and the executive branch, but the combination of parliamentary government and a strong party system leads to the concentration of legislative and executive power in one set of hands: the coalition of parties that won the elections.

REPUBLIC 606-18 (1969) (calling the Constitution "the end of classical politics" and arguing that the Founders chose a liberal over a republican form of government).

135 See Pitkin, supra note__ at 195.

${ }^{136}$ Norway, Sweden, Austria, Denmark, Switzerland, Israel, the Netherlands, Belgium, Japan, Finland, and Luxembourg are some of the democracies that are generally identified as corporatist. See Lijphart, supra note__ at 177. 137 See Helmut Steinberger, Political Representation in Germany, in GERMANY AND ITs BASIC LAW 121, 137-55 (Paul Kirchof \& Donald P. Kommers eds., 1993) 
The constitutional concentration of power in the executive branch enables elected officials to filter carefully which private associations will influence lawmaking. ${ }^{138}$ In drafting bills that touch upon issues such as pension reform and unemployment benefits, bills that are sent later to parliament for debate and voting, the Ministry of Economics regularly consults with peak organizations of management and labor. The same goes for the Ministry of Consumer Affairs and the Federation of German Consumer Organisations and the Ministry of the Environment and environmental organizations. Moreover, advisory boards composed of peak associations of business, labor, consumers, and environmental groups have been established by a variety of sector-specific statutes and ministerial orders. ${ }^{139}$

Private associations influence administrative decisionmaking too, but again the law restricts access to government officials. The same constitutional concentration of power in the executive branch that enables ministry civil servants to consult selectively on proposed legislation also allows them to consult selectively on administrative measures. Parliamentary laws also guarantee certain associations, in specific policy areas, the right to participate in rulemaking and other forms of administrative action that affect classes of firms and individuals. For instance, environmental associations certified by federal and state ministries of the environment can demand to be heard and to inspect expert evidence in rulemaking conducted by nature conservation authorities. ${ }^{140}$ The law, however, does not create a right, applicable in all policy areas and enjoyed by all individuals and associations, to be informed of rulemaking proposals, voice objections, and receive a reply as in the American system. Instead, German law draws a strict line between individual administrative acts (Verwaltungsakt) and generally applicable rules. ${ }^{141}$ When an administrative

\footnotetext{
${ }_{138}$ See generally Adams, supra note__ at 17 (stating that strong state capable of "organizing, recognizing and identifying what groups are to be included in the policy and decision making process" sets corporatist systems off from pluralist ones); Clive S. Thomas, Toward a Systematic Understanding of Party-Group Relations in Liberal Democracies, in POLITICAL PARTIES AND INTEREST GROUPS 269, 275 (Clive S. Thomas ed., 2001) (describing the role of strong parties in serving as gatekeeper to policymaking and importance of cultivating ties with party in order to influence policy process).

${ }^{139}$ For instance, the Consumer Advisory Council (Verbraucherbeirat) includes six consumer associations, three government representatives, three academics, three union representatives, and one member of the press. See Gunnar Trumbull, The Contested Consumer: The Politics of Product Market Regulation in France and Germany 91 (Jan. 2004, unpublished manuscript on file with author). In the environmental policy area, Carol Rose-Ackerman notes that the German government routinely consults advisory committees. See CONTROLLING ENVIRONMENTAL POLICY: The Limits of Public LaW in Germany and the United States 10-11 (1995).

140 See Theodora Th. Ziamou, Rulemaking, Participation and the Limits of Public Law in the USA AND EUROPE 131 (2001).

${ }^{141}$ Mahendra P. Singh, German Administrative Law in Common Law Perspective 63 (2001). The German Administrative Procedures Act does not cover rules. The only procedural requirements are set down in the Basic Law and specific enabling laws. The Basic Law requires that rules be published and that, in certain cases, they be presented to the Bundesrat and/or the Bundestag.
} 
decision is classified as an "act," the law guarantees individuals extensive hearing rights before the administration. By contrast, when an administrative decision is classified as a rule (Rechtsverordnungen or Verwaltungsvorschriften), the law accords administration significant discretion and imposes minimal procedural requirements. ${ }^{142}$

In the German system, intermediate associations are not limited to influencing government policy decisions. The law confers upon certain associations the power to set rules with ramifications not only for their members but also society-at-large--rules which are backed by the state. ${ }^{143}$ For instance, a single industry association, the Deutscher Normenausschuss (DIN), sets technical product and process standards for all of Germany. ${ }^{144}$ An agreement between DIN and the German government dating to 1975 recognizes DIN as the standard-setting body for all Germany and as the national organization entitled to sit in the various international standard-setting organizations in which Germany takes part. ${ }^{145}$ By adopting DIN standards, firms come into compliance with the safety requirements set down in consumer legislation. ${ }^{146}$ The agreement between DIN and the German government imposes certain conditions: the public interest must be protected, including public health, consumer safety, and the environment; and consumers must be represented. ${ }^{147}$ Consumer representation in DIN is assured through a five-member Consumer Council. ${ }^{148}$ Thus, public power comes with state-imposed responsibilities.

\footnotetext{
Moreover, enabling legislation frequently requires the government to lay rules before Parliament. See generally, ZIAMOU, supra note__ at 15-18, 194-96.

${ }^{142}$ Both Rechtsverordnungen and Verwaltungsvorschriften are determinations made by the administration that legally bind an undefined number of persons. The difference is that while Rechtsverordnungen bind individuals outside the administration, the equivalent of a rule or regulation in American law, Verwaltungsvorschriften bind individuals within the administration. The latter are primarily orders issued by senior officials and directed at junior civil servants, the equivalent of certain types of informal rules in American law.

${ }^{143}$ See Steinberger, Political Representation in Germany, supra note__at 123-24.

${ }^{144}$ See Josef Falke, 3 RechtLICHE AsPEKTE DER NORMUNG IN DEN EG-MitGLIEDSTAATEN: DEUTSCHLAND 22 (2000). In 1997, DIN counted 5,734 member firms.

145 See Harm Schepel \& Josef Falke, 1 LEGAL ASPECTS OF STANDARDiSATION IN THE MEMBER STATES OF THE EC AND EFTA: COMPARATIVE REPORT 76 (2000).

146 See Schepel \& Falke, supra note_ at 77 ("DIN is given the task to support the Government by creating, by means of the elaboration of standards, acknowledged rules of technology that enable the reference to standards in legislation."). For instance, under the Law on Safety of Equipment (Gerätsicherheitsgesetz or GSG) equipment is considered safe and therefore liability-proof under the following circumstances: "The producer or importer of technical equipment may only display or circulate goods such that, in accordance with the generally recognized rules of technology as well as the labor protection and accident avoidance regulations, the user or third party to its specified application is protected against all kinds of risk to life and health, as specified by the manner of its particular application." The DIN standards were quickly recognized by the courts as the "generally recognized rules of technology." See Trumbull, supra note_ at 189-90.

147 See Schepel \& Falke, supra note__ at 76; Normenvertrag, art. 1.2 and annotations.

148 See Falke, supra note_at 183.
} 
As in the United States, associations of professionals such as lawyers, accountants, pharmacists, physicians, and veterinarians are entrusted with extensive rule-making and rule-enforcement powers over their members. ${ }^{149}$ In Germany, however, this form of regulation also extends to businesses and trades. By law, to run a restaurant or any other business, or to work as a painter, builder, or in any of the other trades, one must be a member of a local chamber of commerce (Industrie und Handelskammer for businesses and Handwerkskammer for tradesmen). If, for instance, a painter is found by his local chamber to have breached a service obligation, he can be expelled from the chamber and thus be deprived of his livelihood.

The German collective bargaining regime also gives trade unions and employers' organizations public power by putting them in the position of deciding matters for workers and employers throughout the economy, not simply their members. Collective bargaining agreements (Tarifverträge) are governed by the Collective Bargaining Agreements Act (Tarifvertragsgesetz, TVG). ${ }^{150}$ The Act regulates three components of all collective bargaining agreements: entry into the agreement (Abschlußnormen); employment conditions (Inhaltsnormen) such as wages, working time, and dismissals; and internal obligations (Betriebsnormen) such as workplace bans on smoking and limits on workplace surveillance of employees. ${ }^{151}$ Thus, collective bargaining agreements cover a wide array of matters related to the workplace, not simply wages and working time, issues that in the United States are generally regulated by federal and state administrative agencies. Moreover, while, as a general rule, a collective bargaining agreement only binds those firms that signed the agreement through the intermediary of their employers' association, the Act permits, under certain circumstances, the Minister of Labour and Social Order to declare the agreement generally binding (allgemeinverbindlich) on all firms in the industry. ${ }^{152}$

Turning to the courts, there too German law gives certain intermediate associations the right to influence public policymaking. Although not even associations are allowed to bring pre-enforcement challenges to administrative rules, as allowed under American law, certain intermediate associations are empowered to enforce public interest statutes. ${ }^{153}$ This form of associational

\footnotetext{
149 This area of law is called Standesrecht. The codes of conduct issued by the free professions (Freie Berufe) are known as Ordnungen der Berufsstände and violations of the codes are litigated before special courts of honor (Ehrengerichte). See, e.g., Federal Act for Attorneys-At-Law $\S \S 43$ et seq. (Bundesrechtsanwaltsordnung or BRAO).

150 See Basic Law, art. 9(3); Däubler, Tarifvertragsrecht, 3. AufL. (1993); Löwisch \& Rieble, TARIFVERTRAGSGESETZT ( $2^{\text {nd }}$ ed., 2004).

${ }^{151}$ Collective bargaining agreements apply to all workers in the firm, regardless of whether they are members of the trade union.

${ }^{152}$ Collective Bargaining Agreements Act $\S 5$.

153 Only when the rule is enforced against an individual or firm does the law recognize an "administrative act" (Verwaltungsakt) that prejudices the rights of a party, which can then be challenged in the courts by that party. At that point, the party can claim that the rule upon which
} 
lawsuit is known as a "class action" (Verbandsklage) and enables associations to sue in their own right, without having to establish that an individual member has legally recognized rights that have been injured. ${ }^{154}$ Verbandsklage have the advantage over individual lawsuits that a judicial remedy can be awarded to the entire class of individuals represented by the association, not simply the named plaintiffs. Since the 1940s, local chambers of commerce (Industrie und

Handelskammer), competitors (Gewerbetreibende), and industry associations, whose by-laws specify among their aims the pursuit of their members's commercial interests, have had the right to sue businesses guilty of anti-competitive practices under the Unfair Competition Act. ${ }^{155}$ The same associations, plus trade unions, also have the right to sue for infringements of various consumer protection laws. ${ }^{156}$ Then, in the 1970s, a number of statutes empowered consumer and environmental groups to bring lawsuits enforcing their terms. In 1976, consumer associations with more than seventy-five members and accredited by the Economics Ministry were allowed to sue to obtain injunctive relief under the law on misleading advertising and unfair standard contracts. ${ }^{157}$ In 1979, Bremen gave certain environmental organizations the right to sue for breaches of the Bremen Environmental Protection Act and, in 1980, the Land of Hesse did the same. ${ }^{158}$ Under the Federal Nature Conservation Act, passed in 2002, environmental groups may sue to oppose public and private schemes with environmental effects and to contest administrative waivers from the requirements of the Act. ${ }^{159}$

In corporatist democracy, in contrast with pluralist democracy, the law permits only certain associations take part in day-to-day lawmaking, rulemaking, and enforcement, yet the law also confers greater public authority upon those

the enforcement action was based is illegal. Notice, however, that the range of parties that can object to the rule is limited by the requirement of an act directed against a specific party, and the arguments that can be used to oppose the rule do not include the procedural claims in American administrative law, given the lack of a right to participate in administrative rulemaking. ${ }^{154}$ Absent such statutory authorization, associations are not allowed to sue on the behalf of their members. A litigant must allege that the administrative act violated his or her own "subject rights." See VwGO § 42.2 .

${ }^{155}$ Gesetz gegen unlauteren Wettbewerb (Act Against Unfair Competition) § 13.2.2; Köhler and Piper, Gesetz gegen den unlauteren Wettbewerb, 3 $3^{\text {rd }}$ ed., Munich 2002, § 13 note 11 (right to sue of Gewerbetreibende), § 13 notes $17 \& 20$ (right to sue of industry associations).

${ }^{156}$ Gesetz zur Regelung des Rechts der Allgemeinen Geschaftsbedingungen (Unfair Contract Terms Act) $\S 22.3 .1 .2$

157 See Unfair Contract Terms Act § 13.2.1.2; Trumbull, supra note_at 78, 96. Since January 1, 2002, the Unfair Contract Terms Act has been repealed and has been incorporated into a number of other laws. The provisions on Verbandsklage are now section 3.1.1.2 of the Prohibitory Injunctions Act (Gesetz über Unterlassungsklagen bei Verbraucherrechts--und anderen Verstößen).

158 See Bremisches Naturschutzgesetz (Bremen Environmental Protection Act) §§43, 44; Hessisches Naturschutzgesetz (Hessian Environmental Protection Act) § 36.

159 See Bundesnaturschutzgesetz $\S 61$. Many of the consumer and environmental associations that are given the right to sue also receive large amounts of direct government funding. This is the case for the German Consumer Federation (Vzbv). 
same associations. What are the cultural norms and beliefs that underpin the public law of associations in corporatist democracy? Industry, labor, the trades and the professions, consumers, and environmentalists are believed to constitute society. ${ }^{160}$ Membership in one of these groups is a matter of identity and belonging. The fabric of the nation has many threads, some which are ideological in nature and expressed through party affiliation and elections, others which are related to the structure of the market and production of wealth, others which are tied to family and community. In corporatism, when interest groups are consulted or when they are allowed to govern, they are conceived as acting in the public interest because, on certain matters, they are the public.

This ideology can be traced to different nineteenth-century and early twentieth-century theories of the state and society. To mention just a few of the strands Philippe Schmitter identified in his now classic analysis of modern corporatist practices: the romantic, organic thought of Friedrich Schlegel and G.W. Friedrich Hegel; the Social Christian thought of Wilhelm von Ketteler, Karl von Vogelsang, Popes Leo XIII, and Pius XI; the fascist authoritarian thought of Giuseppe Bottai and Francesco Vito. ${ }^{161}$ Some of the intellectual pedigree is suspect, but then again, some of it is not. This form of interest accommodation has co-existed happily with elections, legislative assemblies, and constitutional courts for over fifty years now. The less fortunate ideological origins of the public law of corporatist democracies should not prejudice contemporary attitudes towards corporatist forms of interest representation.

A corollary of the idea of intermediate association as building block of the nation is the necessity of distinguishing between associations which represent and constitute broader identities and those which simply serve as temporary conduits for the shifting preferences of individuals. In corporatist systems, not all associations are created equal. Just because an organization has a charter and members does not mean that it should be allowed to take part in policymaking or set rules for its members, and by implication, all citizens who interact with its members. The organization must satisfy certain conditions before it will be recognized as representing broader social identities: recognition from those whom it purports to represent, namely membership, recognition from other associations, longevity, and so on.

The importance that corporatist democracies attach to public identities other than nation does not mean that they denigrate the institutions of citizenship--voting, parties, and elected representatives. Although it is certainly true that corporatism has been used by authoritarian regimes--Mussolini in Italy,

\footnotetext{
${ }^{160}$ Most political science studies of corporatism focus on peak associations of capital and labor and their influence on labor market, social welfare, and economic policies. See Lijphart, supra note _ at 176. As new interests have emerged in areas such as consumer protection and the environment, corporatist democracies have extended the old patterns of representation to the new forms of interest and therefore I include these actors and policy areas as well.

161 See Schmitter, Still the Century of Corporatism?, supra note_at 87.
} 
Franco in Spain, and a number of Latin American countries--corporatist interest representation is also an important feature of established democracies such as Sweden, Norway, and the Netherlands. ${ }^{162}$ Part of why public law permits legislators and administrators to select the interest associations that will influence policymaking is because elected representatives are trusted institutional actors. Today, as the German Constitutional Court declared in the case on the constitutionality of the Maastricht Treaty, at the heart of the German nation are elections and the Bundestag, the "representative of the whole people."163 Because of the choice made in the Basic Law in favor of parliamentary government, the elected officials that head the executive branch wield significant powers. They are free from some of the checks of the American separation of powers system, and rightly so in the eyes of the citizenry. As we shall soon see, however, the executive branch in corporatist democracy is subject to greater checks than in republican democracy, precisely because of the role of intermediate associations in public decisionmaking.

A strong, elected executive branch that commands a professional bureaucracy has a high capacity for action. Once a choice is made in a general election in favor of a party and its platform, government faces fewer obstacles to carrying out that choice in corporatist democracy than in the pluralist variety. Legislation and implementing measures can be adopted with relative ease, given the relationship between coalition parties, the government cabinet, and the administration in drafting and shepherding the text through the government process. Not as great a capacity for state action as in the case of French republican democracy, however, because of the need to include and accommodate important social and economic forces. Again, the ability to act decisively in public affairs and pursue new policy initiatives is not simply a matter of the institutional mechanics of corporatist democracy; it also informs the expectations of the citizens who mobilize and organize within the world of corporatist democracy. In this idea of democracy, once officials are elected to office, they should be able to be carry out their policy agenda, checked only by significant social forces, because those officials are considered representatives of the people and, as such, able to make the right decisions for the nation.

\section{Republican Democracy}

In republican democracies, decisionmaking is dominated by the institutions of voting, political parties, elected leaders, and specialized administration, with little room for private associations. France is the paradigmatic case, although even there interest and identity associations are

\footnotetext{
${ }^{162} I d$. at $89-90$.

${ }^{163}$ Brunner and Others v. The European Union Treaty, Case 2 BvR 2134/92 \& 2159/92 [1994] 1

CMLR 57, Oct. 12, 1993.
} 
becoming increasingly influential in day-to-day policymaking. ${ }^{164}$ Like Germany, the origins of the French system are parliamentary. The Constitution of the Fifth Republic, however, establishes a semi-presidential system: a directly elected President appoints the Prime Minister, but the Prime Minister must also enjoy the support of the party or coalition of parties that wins the elections for parliament (Assemblée Nationale). ${ }^{165}$ This might appear to create the possibility of divided government, with the concomitant multiple points of access for interest groups. Historical experience, however, has shown that during those periods in which the offices of the Prime Minister and the President are held by different parties, the Prime Minister dominates. ${ }^{166}$ The Prime Minister and his cabinet work with an elite, professional administration to draft legislation. Unlike Germany, the concentration of legislative power in the hands of the Prime Minister, or the Prime Minister and President when they are both of the same party, is used more to exclude interest groups, and less to screen them. ${ }^{167}$ Different ministries with historical ties to certain groups may call upon them to comment on draft bills, yet the process is less systematic than in the German system. The law also establishes a number of government bodies on which employers' associations, professional associations, labor, farmers, consumers, and other groups are represented and which are consulted in the lawmaking process. ${ }^{168}$ The influence and pervasiveness of such advisory bodies in public life, however, is less significant than in the German case. ${ }^{169}$

Rulemaking and other forms of policy implementation follow a similar pattern. Drafting is a matter for the administration, with the exception of those cases in which civil servants seek guidance from outside groups because such groups are believed to have valuable experience or the issues are thought to be politically sensitive. Some of the same advisory bodies that consult on draft legislation also consult on important implementing rules (règlements). As in

\footnotetext{
${ }^{164}$ Other such democracies are Greece and Malta. This classification is based on Schmidt and Lijphart. Schmidt groups France and Greece together as "simple polities." See Schmidt, supra note__ at 115. In Lijphart's analysis, Malta score high on interest group pluralism (indicating that historical relations between state and society have not created incentives for interest groups to organize into a small number of peak associations) and executive dominance (indicating that the numerous interest groups do not have access to public decisionmakers because of the concentration of power in the executive branch). See Lijphart, supra note__at 138, 177. I have excluded common law countries like the United Kingdom and Australia from this list because, even though they share a number of features with France--a strong state that bars extensive interest group participation in public decisionmaking,--they do not share the same republican ideology.

165 See FRENCH CONST., arts. 8 \& 20; see generally Mark Kesselman, France, in EUROPEAN POLITICS IN TRANSITION 127 (Mark Kesselman \& Joel Krieger eds., 1987).

166 See Lijphart, supra note__ at 121-22.

167 See Andrew Appleton, France, in POlitical Parties AND InTERest Groups 45, 54 (Clive S. Thomas ed., 2001) (describing ability of executive branch to control points of access of interest groups because of elite status and professional ethos of civil service).

168 One prominent example is the Social and Economic Council, which, under the Constitution, must be consulted on all economic and social legislation. See FrENCH CONST., arts. 70 \& 71.

169 See Mény, supra note__ at 144-46.
} 
Germany and different from the United States, the law does not guarantee associations outside advisory committees the right to be consulted. The law draws a line between administrative decisions of general application (acte réglementaire) and individualized determinations (acte individuel) and only guarantees procedural rights before the administration in the latter case, generally only for individuals named in the administrative proceeding. ${ }^{170}$

Private associations are also entrusted with regulatory powers, albeit less often and with greater government participation than in Germany. The law authorizes a single standard-setting organization, the Association Française de Normalisation (AFNOR), to adopt industry standards, which are often incorporated in health and safety and consumer protection laws and therefore become legally binding. ${ }^{171}$ AFNOR is composed mainly of sector-specific industry associations, but also has representation from trade unions, consumer groups, and environmental organizations. In contrast to the German case, the French government directly participates in the standard-setting work of AFNOR: a government representative (commissaire du gouvernement) sits on AFNOR's governing board and can initiate new standards projects, comment on proposed standards, and veto standards. ${ }^{172}$ Similar to Germany, the law requires firms to join their local chambers of commerce (chambre de commerce), which exercise regulatory and disciplinary powers over their members. ${ }^{173}$ Members of the professions must join their national association (ordre), which is responsible for drawing up professional codes of conduct (codes de déontologies) and enforcing the terms of the code through their governing bodies (Conseil de l'ordre). ${ }^{174}$ Although professional associations exercise this form of public power everywhere, including the United States, their authority is more extensive in France: in the case of doctors, dentist-surgeons, mid-wives, and pharmacists, their national governing bodies decide disputes between their members and patients covered under the state social insurance scheme. ${ }^{175}$

French law on the right of citizen associations to shape public policy through the courts stands somewhere between American and German law. Like the United States and unlike Germany, standing (intérêt à agir) to bring preenforcement challenges to administrative regulations is liberal. ${ }^{176}$ Associations are normally permitted to sue on the behalf of the general interest (intérêt général

\footnotetext{
170 See JaCQueline Morand-DeVILler, COURS De Droit AdMinistratif 317 (7th ed. 2001); MARCEAU Long, Prosper Weil, Guy Braibant, Pierre Delvolvé \& Bruno Genvois, Les grands arrêts de la JURISPRUDENCE ADMINISTRATIVE 355, point 7 (14th ed. 2003).

171 See Schepel \& Falke, supra note__ at 71.

172 See id. at 72.

173 See Mény, supra note__ at 144-46.

174 See Jö̈l MORET-BAILly, LEs DÉONTOLOGIES 99-126 (2001).

175 See id. at 184.

176 See MORAND-DEVILLER, supra note_ at 679. However, unlike citizens in Germany and the United States, French citizens and their associations cannot bring constitutional challenges to parliamentary laws. See Ferejohn \& Pasquino, supra note _.
} 
or intérêt collectif) that they are charged with protecting under their by-laws. ${ }^{177}$ The grounds of review, however, are narrow since plaintiffs are not guaranteed procedural rights in the administrative process and therefore can only challenge the rule on the substance, not the procedure. ${ }^{178}$ Furthermore, the degree of judicial interference with the government's findings on the substance is not particularly extensive since the government is allowed significant discretion in the rulemaking context. ${ }^{179}$

Again, with respect to associational enforcement of public interest statutes, the French system also falls somewhere in between the American and German systems. The law puts into place a number of cross-cutting requirements that associations must satisfy before they can bring suit. Since there are requirements, the litigation opportunities are not as significant as in the American system; but since the requirements are cross-cutting, and not tied to particular regulatory statutes, the litigation opportunities are greater than in the German system. Traditionally, associations were allowed to sue to protect their property rights and to represent the legal interests of their members--in common law parlance, a claim sounding in tort, contract, or property--but not to vindicate the broader public interest goals contained in laws. Only the public prosecutor was recognized as the legitimate spokesman for the public interest. As one standard text on the subject puts it:

Before, judges did not want to give to groups that were not necessarily representative the power to represent the collectivity. Generally speaking, they feared that civil actions, brought before the courts by single associations, would encroach upon the powers of the public prosecutor. ${ }^{180}$

Beginning in the early 1970s, judicial resistance to associational litigation gave way to a more liberal approach and now associations are allowed to sue if the interest being vindicated is consistent with their purposes under their bylaws (statuts) and as declared to the public authorities. ${ }^{181}$ For instance, in 1971, a Holocaust remembrance group (Reseau de Souvenir) petitioned to join, as a civil party, a criminal prosecution against Le Pen for publishing material favorable to Hitler and the Nazis. Reseau de Souvenir was registered with the Ministry of Interior as a public purpose association (association d'utilité publique) created to protect the memories of those murdered in concentration camps. The Court of Cassation decided in favor of Reseau de Souvenir, even though Reseau had failed to prove that any single member suffered injury from Le Pen's publication

\footnotetext{
177 See id. at 679-80.

178 See id. at 684.

${ }^{179} \mathrm{Id}$. at 261.

180 See Charles DebBasch \& Jacques Bourdon, Les Associations 82 (8th ed. 2002) (my translation).

181 See DEBBASCH \& BOURDON, supra note__ at 83
} 
and even though Reseau's injury was indistinguishable from that of its members. ${ }^{182}$

A number of laws have also specifically recognized the right of associations to litigate in the public interest: environmental organizations, consumer organizations, animal rights groups, and civil liberties groups. ${ }^{183}$ These laws, however, all impose additional conditions beyond the courts' requirement that associations be registered as public purpose associations whose aims are related to the interests protected by the statute. For instance, consumer groups must demonstrate at least one year of existence and "effective and public activity" in defense of consumer interests. Furthermore, national consumer associations must have at least 10,000 members while local associations must have a "sufficient" number of members. ${ }^{184}$

Before concluding this overview of the French public law of associations, one unusual feature should be noted, an anomaly which suggests a greater suspicion of private associations in public life than in the American or German cases. In the United States, associations are generally not required to register with the public authorities unless they wish to claim tax-exempt status. In Germany, voluntary associations (Vereine)-- among the most common are sports clubs and singing clubs--are required to register with the local court (Amtsgericht), which keeps what is called the Register of Associations (Vereinsregister). Registration confers the association with legal personality, enabling the association to enter into contracts, buy property, appear in court, receive gifts and bequests, and engage in other legal relations under the Civil Code. The requirements are minimal: associations must have at least seven members and file articles of association that cover certain matters. ${ }^{185}$

The French registration scheme is more elaborate and demanding than in either the American or German cases. In the 1800s, the Penal Code required that all associations with over twenty members obtain authorization from the state or face stiff criminal penalties. ${ }^{186}$ In 1901, the Penal Code provision was replaced with a law, which still exists in a substantially modified form today. That law establishes three types of associations, each of which is subject to a progressively more stringent form of public supervision: non-declared, declared, and public purpose associations. Any group of two or more persons can form a nondeclared association without registering with the authorities by adopting a set of by-laws (statuts) to govern their activities. In the past, such associations were at a disadvantage because they could not appear in court to challenge administrative

\footnotetext{
182 See Cour de cassation, 14 January 1971 (Association "le Réseau du Souvenir").

183 See DEBBASCH \& BOURDON, supra note_, at 83-84.

${ }^{184}$ Loi no. 88-14 du 5 janvier 1988 (Loi relative aux actions en justice des associations agréés de consommateurs et à l'information des consommateurs), codified at Article R411-1, Code de la Consommation.

185 See German Civil CODE, §§21, 55-79.

186 See GILLES Lebreton, LiberTÉS PUbliQue ET DROIT DE L'HOMME 495 (5th ed. 2001).
} 
acts or enter into contracts; today, non-declared associations generally enjoy these basic rights before the courts. The second type--declared associations--can hold property, enter into contracts, and litigate in their own name. Such associations must file certain information with the local prefect (préfet) ${ }^{187}$ and must maintain a special register in which they note all significant acts of the association, to be presented on demand to the authorities. ${ }^{188}$

We have already seen the third type of association--public purpose associations--in the discussion of associational litigation. These citizen associations are significantly different from the previous two, both in the activities they can undertake and the degree of state supervision they undergo. ${ }^{189}$ Public purpose associations are entitled to receive donations and bequests and may, depending on whether the law sets down additional requirements, bring the public interest litigation described earlier. To qualify, an association is required to file an application with the Ministry of Interior. The decision to grant the application is based on a number of criteria: the association pursues the general interest (intérêt général); its the scope of action extends beyond the purely local; it has a significant number of members; it has sufficient resources; and it has existed for at least three years. ${ }^{190}$ Once an association is approved, it must keep its books and premises open for inspection and it must file annual reports with the authorities. ${ }^{191}$

The common wisdom among legal scholars is that the original statutory scheme was driven by the fear of "the triumph of particular interests over the general interest" and the desire to prevent private associations from competing with the state. ${ }^{192}$ The intent was to curb the accumulation of property and power outside of the state. French politics has long since lost this Rousseau-tinted hostility towards citizen associations, but the fact of state regulation of such associations remains--regulation that does not exist in the United States or Germany.

What, then, are the understandings, preferences, and beliefs that sustain the republican system of citizen associations in democratic decisionmaking? In republican democracy, the law, through liberal rights of free expression and association, creates an ample public sphere in which citizens can join together and debate the issues of the day. The law, however, does not afford citizen groups the same opportunities to influence legislators and bureaucrats as in pluralism and corporatism, nor does the law afford the same opportunities to

\footnotetext{
${ }^{187}$ The prefect is the public official charged with representing the state and administering the law at the local level. See Agathe VAn LAnG, Geneviève Gondouin \& VÉROnique InSERGuet-Brisset, DICTIONNAIRE DE DROIT ADMINISTRATIF 239 (3d ed. 2002).

188 See DEBBASCH \& BOURDON, supra note__ at 111.

189 See LEBRETON, supra note__ at 502.

190 See DEBBASCH \& BOURDON, supra note__ at 40.

191 See id. at 111-12.

192 See id. at 14-17.
} 
influence judges as in pluralism. That is because, unlike Germany, interest associations are believed to pursue narrow and selfish aims. ${ }^{193}$ And, unlike the United States, the response to this understanding of interest is to exclude private associations from lawmaking and administration and to screen them before they can appear in court. The response is not, as in the United States, to open the doors of government to all interests so that they can check and balance one another. In republican democracy, no matter how many different associations and interests are called to participate in politics, they are not believed capable of transcending their particularities and constituting the people.

The French idea of democracy can be traced to the political theory of Rousseau as popularized in the Jacobean phase of the French Revolution. According to this version of Rousseau, citizens owed their primary allegiance to the Republic and had to ratify, directly, all laws of the Republic. All other loyalties based on the Church, status and trade were considered illegitimate. ${ }^{194}$ Obviously, French democracy has changed considerably since then. Yet, through public law and political thought, some of the basic principles have survived. ${ }^{195}$ Citizens do not wish to participate in politics through the intermediary of interest groups and interest group elites to the same extent as their pluralist cousins, nor do they believe that a political community in which such interest politics prevail is a viable one, not to speak of a good one.

The rejection of interest groups in the daily government activities of lawmaking, administration, and judging is related to the importance attached to the democratic institutions of voting, parties, and elected officials. At the center of the French legal system is not the Constitution nor the decisions of the Constitutional Court, but la loi--parliamentary statutes-because all citizens are believed to be able to participate in their making, either personally or through their elected representatives. ${ }^{196}$ As Article 6 of the Declaration of the Rights of Man says:

The law is the expression of the general will. All citizens have the right to contribute personally or through their representatives to their making.

\footnotetext{
193 Peter A. Hall, Governing the Economy: The Politics of State InTERVEntion in Britain and FRANCE 165 (1986).

194 See Hanna Fenichel Pitkin, Representation, Political InNovation and Conceptual Change 132, 149 (Terence Ball et al. eds., 1989); Michael A. Walzer, Citizenship, in Political InNOvation AND CONCEPTUAL ChANGE 211, 211 (Terence Ball et al. eds., 1989).

195 See, e.g., RENÉ CAPITANT, DÉMOCRATIE ET PARTICIPATION POLITIQUE 7-36 (1971) (linking contemporary institutions of French representative democracy to Rousseau and contrasting with the democratic tradition of Locke).

196 See Etienne Picard, Delegation of Legislative Power, in French Public LAW, Delegated LegisLation AND THE Role OF COMMITTEES IN THE EC 67, 74-81 (Mads Andenas \& Alexander Türk eds., 2000).
} 
Glorification of la loi, like suspicion of interest groups, bears the heavy imprint of the French Revolution and the active citizenship ideal. It certainly does not represent contemporary French democratic theory. Yet this understanding still informs the types of activities that French citizens value in public life-voting rather than lobbying and other forms of interest group activity. Moreover, the primacy of voting and parliamentary assemblies in French political thought is linked to beliefs about the dangerous consequences of downgrading elections to one among many other of political activity, of the same importance as membership in interest associations.

Finally, even more so than corporatist democracy, French citizens inhabit a political world in which the state has a high capacity for action. The ideology of la loi is combined today with a strong executive branch characteristic of parliamentary systems and a centralized bureaucracy. In France, the government is even more powerful than in Germany, where important social and economic interests can delay or stop public policy initiatives, and where the Constitutional Court and federalism impose considerable constraints. Once the French Prime Minister and President (if of the same party) are elected into office, they can carry out their mandate rapidly, free from some of institutional checks that characterize the American and French systems.

My account of republican democracy, even more so than of pluralist and corporatist democracy, is highly stylized. As the French law of citizen associations illustrates, even the constitutional system that typifies republicanism today departs dramatically from the ideal type and allows private associations to influence significantly the daily workings of government. Yet that does not mean that the different law and culture of democracy has been eradicated. As the changing French law of associational standing demonstrates, even though a republican democracy might come to permit more associational participation in law enforcement, it does so through a uniquely republican set of legal practices: the interest that was considered particular is rendered general through the intervention of the state and the recognition that the association serves the general interest.

At the risk of slipping into caricature, the differences that separate contemporary democracies on the appropriate role for private associations in public life can be summarized as follows. When an American gazes across the Atlantic she sees capture by special interests in Germany, authoritarianism in France. When a German or Frenchman looks in the direction of her American cousins, she sees anarchy in which, ultimately, the most powerful economic interests prevail.

\section{The Role for Civil Society in Global Democracy}

It is time to return to the questions from the beginning of the Article.

Should World Bank executive directors and civil servants be required to solicit 
the reaction of civil society before they approve loans? Should environmental groups and others be called upon to participate in the work of the WTO's Committee on Trade and the Environment? How should the Constitutional Treaty provision on civil society consultation in the European Union be interpreted? In sum, what should be the role of civil society in a democratic system of global governance?

The comparative law of democracy shows that each of these questions can be answered in at least one of three ways: all, some, or none of the associations between the state and the market should be entitled to participate in the institutions of global governance. Appreciation and tolerance of legitimate differences on the civil society question and self-awareness of the inevitable bias that comes from being a citizen of one of the many cultures of democracy, is the first lesson to draw from this analysis. But for those wrestling with the issue in the global arena, for whom this conclusion is not particularly satisfying, we can go one step further.

Following the lead of critical theory, we might predict that American governmental and non-governmental actors will foist their pluralist model on institutions of global governance, using their power and resources as citizens of the hegemon. ${ }^{197}$ Indeed, the recent history of international organizations contains some evidence of such attempts at transforming the law in America's image. In the negotiations on Chinese accession to the WTO, the United States demanded, successfully, that China introduce domestic administrative law reforms that would approximate the participation rights contained in the U.S. Administrative Procedure Act. ${ }^{198}$ When the European Commission circulated a proposed set of guidelines on civil society consultation, the U.S. government replied that the guidelines should apply, without exception, to all Commission initiatives, should never be used to favor certain groups over others, and should be enforceable in the courts. In other words, the U.S. government replied that the European Union, like China, should adopt the U.S. Administrative Procedure Act. ${ }^{199}$ The European Commission, unlike China, said "no."

\footnotetext{
197 See generally David Kennedy, When Renewal Repeats: Thinking against the Box, in LEFT LEGALISM/LEFT CRITIQUE 415 (Wendy Brown \& Janet Halley eds., 2002) (describing critical approach to public international law).

198 See Protocol on the Accession of the People's Republic of China, Part I.2 (C) ("Transparency"), WT/L/432, 23 Nov. 2001.

${ }^{199}$ See Communication from the Commission, Consultation Document: Towards a reinforced culture of consultation and dialogue--Proposal for general principles and minimum standards for consultation of interested parties by the Commission, June 5, 2002, COM (2002) 277 final; Comments of the United States Government on the European Commission's Better Regulation Package at 2-9 (2002), available at: http://europa.eu.int/comm/secretariat_general/sgc/consultation/index_en.htm; Communication from the Commission, Towards a reinforced culture of consultation and dialogue--Proposal for general principles and minimum standards for consultation of interested parties by the Commission, Dec. 11, 2002, COM(2002) 704 final, at 8-14.
} 
From a critical perspective, a successful bid to transpose American-style pluralist participation to the international realm would constitute an act of exclusion. Of whom? First, the same individuals and groups that are disadvantaged by pluralist institutions in domestic, American politics. But understanding precisely which groups are systematically advantaged and disadvantaged by the configuration of rights and procedures in a pluralist order is not a simple task. Take one piece of the American pluralism, notice and comment rulemaking. Mark Seidenfeld and Cass Sunstein separately argue that American rulemaking furthers the ideals of deliberative democracy, that is, reasoned public deliberation among the citizens, bureaucrats, and judges involved in rulemaking. ${ }^{200}$ According to Seidenfeld and Sunstein, affected citizens put forward their concerns, administrators listen and respond based on the universalist grounds of good scientific evidence and the enabling statute's overall policy goals, and the courts oversee the entire process to ensure that the bureaucrats are deciding based on public reasons. This procedure stops citizens from putting forward narrow, self-interested arguments and stops bureaucrats from striking deals that satisfy the most powerful participants in the process.

Not so, argues Thomas McGarity. American rulemaking in his view "works to the advantage of powerful entrenched economic interests."201 Why is this the case? Regulated business is more likely to take part in rulemaking in the first place. ${ }^{202}$ The interest of economic actors is to delay the promulgation of rules since the later they must comply, the less they must spend. Moreover, trade associations and firms have the resources necessary to participate effectively, resources which are generally lacking in the public interest sector. Lastly, the American judges that enforce such procedural rights on judicial review impose the demanding standard of "comprehensive analytical rationality." Regulators can rarely meet this standard because they operate in the

\footnotetext{
200 See Cass R. Sunstein, Interest Groups in American Public Law, 38 STAN. L. Rev. 29, 60-64 (1985); Cass R. Sunstein, Factions, Self-Interest, and the APA: Four Lessons Since 1946, 72 VA. L. REV. 271 (1986); Mark Seidenfeld, A Civic Republican Justification for the Bureaucratic State, 105 HARV. L. REV. 1511, 1560 (1992); Steve P. Croley, Theories of Regulation: Incorporating the Administrative Process, 98 COLUM. L. Rev. 1, 156-58

201 See Thomas O. McGarity, The Courts and the Ossification of Rulemaking: A Response to Professor Seidenfeld, 75 TEx. L. ReV. 525, 531 (1997). McGarity accepts public participation in rulemaking. See Thomas O. McGarity, Public Participation in Risk Regulation, 1 RISK: Issues HEALTH \& SAFETY 103, 112 (1990). However, it appears that he would do away with cost-benefit analysis and most judicial review, including judicial review of an agency's fulfillment of the procedural requirements of rulemaking.

${ }^{202}$ A number of studies document the greater presence of trade associations and regulated firms as compared to consumer groups and environmental protection groups in rulemaking. See Steven P. Croley, Theories of Regulation: Incorporating the Administrative Process, 98 CoLUM. L. REV. 1, 127- 33 (1998); McNollgast, The Political Origins of the Administrative Procedure Act, 15 J. L. EcON. ORG. 180, 186 (1999) ("formalized procedures advantage organized interests, which makes possible the frequent observation that regulated firm sometimes capture regulatory agencies").
} 
real world of scientific uncertainty, unquantifiable benefits, and practical and political difficulties in pursuing certain policy alternatives.

Even supposing Sunstein, Seidenfeld, and McGarity were able to agree on whether American pluralist rulemaking systematically favored certain interests over others, their assessment might vary over time. For instance, the low capacity for state action in pluralist systems might make redistributive measures more difficult to enact than elsewhere, yet once in place, that very same inability to act might make it more difficult to dismantle the welfare state. ${ }^{203}$ To return to the initial point, understanding the injustice caused by the different laws of democracy is a formidable endeavor.

Easier to assess is the exclusion of other cultures of democracy that would result from the adoption of a pluralist model. The choice of pluralism would inevitably exclude corporatism and republicanism. A number of political scientists have explored this phenomenon in the context of the European Union, where a common set of European institutions and laws are superimposed on different national cultures of democracy. Predictably, the political scientists prefer the term "fit" to "repression" but the idea is quite similar. They argue that the better the fit between the structure of European governance and the national political system, the smaller the transformation in domestic processes; vice versa, the poorer the fit, the greater the transformation. ${ }^{204}$ Yet even the more significant changes that have occurred in the "misfit" countries do not appear to be particularly troubling. Countries such as France have witnessed a decline in executive branch power, an increase in the powers of the judiciary, and an expansion of the prerogatives of regional government in relation to central government. ${ }^{205}$ One set of constitutional practices is replaced with another set, both of which have good and bad consequences for democratic ideals.

Political scientists have also observed that government and private actors from "misfit" countries must adapt more extensively than actors from "fit" countries to operate effectively in the different institutional environment of Brussels. Interest participation is one area in which European procedures and institutions differ from national democratic practices. With the many

\footnotetext{
${ }^{203}$ See Evelyne Huber \& John D. Stephens, Development and Crisis of the Welfare State: Parties and Policies, in GLOBAL MARKETS 82 (2001) (arguing that political systems with multiple veto points for interest groups are less likely to construct strong welfare states); Duane Swank, Political Institutions and Welfare State Restructuring: The Impact of Institutions on Social Policy Change in Developed Democracies, in The New Politics of the Welfare State (Paul Pierson ed., 2001) (arguing that such political systems are less likely to give rise to heavily redistributive welfare states but also make it more difficult to unravel the welfare state once in place).

${ }^{204}$ See Schmidt, Europeanization of National Democracies, supra note_at 113; Adrienne Héritier \& Christoph Knill, Differential Responses to European Policies: A Comparison, in DifFERENTIAL Europe: New OpPortunities AND CONSTRAints FOR NATIONAl POlicy-MaKing 257 (Adrienne Héritier et al. eds., 2001); Christoph Knill, The Europeanisation of NATIONAL AdMINISTRATIONS: PATtERnS OF Institutional CHANGE AND PERsistence 46-50 (2001).

205 See Schmidt, Europeanization of National Democracies, supra note_at 118.
} 
opportunities it affords for interest group participation, the European Union is a "quasi-pluralist" polity. ${ }^{206}$ Vivien Schmidt argues that because French organized interests come from a republican tradition in which they have few opportunities to influence policymaking, they have had difficulties mobilizing and pressing their agendas in Brussels. ${ }^{207}$ By contrast, German organized interests have significant experience with this form of democracy, coming from a corporatist system in which intermediate associations regularly shape public policy, and therefore they have been quite successful in Brussels. From an equity perspective, this is troubling.

Yet it appears that even this well-established form of exclusion caused by adopting one model of democracy over the others is quickly overcome.

According to Schmidt, national actors have not wasted much time in adapting to the new realities of European politics; today, even French organized interests are quite adept at getting their way in Brussels. ${ }^{208}$ Moreover, as was stressed at the outset of the discussion of the different models of associational participation, none of them is monolithic even within the country believed to exemplify the model; therefore, in certain policy areas, domestic actors may very well be familiar with the alternative mode of democracy. There is an even more basic reason for not taking this form of exclusion too seriously: when a regional or global political space emerges and a single set of constitutional rules must be devised, such rules will inevitably depart more radically from some national constitutional practices than others. If the World Bank or the WTO were to resist the pressure to Americanize and were to decide that civil society participation should be organized along the lines of German corporatism, a culture would still be excluded, just a different one. International organizations and global regimes are indispensable, but they also have costs.

How are national officials and international bureaucrats to make a principled choice among the different models? Recall that, in the discussion of the public law of interest accommodation, the values and beliefs sustaining that public law were identified. While it may very well be impossible to say whether these popular theories of democracy are right or wrong when they operate in the native soil of a national community, we can inquire whether their beliefs find support in the empirics of emerging global communities.

Citizens in pluralist democracies value competition among multiple interests and identities; they believe that public welfare can emerge from this form of political engagement. In the global realm, however, it appears that commercial interests mobilize more than other types of interests and that citizens of northern countries band together in associations more than their counterparts in southern countries. Many observers believe that multinational corporations

\footnotetext{
${ }^{206}$ I would place the emphasis on "quasi" since considerably more effort is made to screen and select interest associations than in American pluralism.

207 See Schmidt, Europeanization of National Democracies, supra note_ at 120.

208 Id. at 120 .
} 
and business lobbies, with their superior financial resources, are better organized than public interest groups. ${ }^{209}$ Similarly, northern NGOs significantly outnumber southern NGOs. ${ }^{210}$ To speak with the language and metaphors of the pluralist tradition, special interest not pluralist competition is the reality of global politics; international institutions would be captured by corporate interests and public interests from the North. In the new terrain of global governance, adopting the public law of pluralism would fall short of the aspirations of that law.

Citizens in republican democracies believe that directly elected officials should be at the center of public life, with little interference from private associations or other institutional actors. Research on regional and global regimes, however, has shown that when power is transferred to the global realm, national voters, parties, parliaments, and even leaders of executive branches, lose control. $^{211}$ Regulators and politicians who make decisions in institutions of global governance do so largely free of party and parliamentary oversight. Under these conditions, republican laws and institutions that would permit global policymakers to exclude non-state actors could not hope to achieve the ideals of representative democracy that underpin such constitutions.

\footnotetext{
209 See Maura Blue Jeffords, Turning the Protester into a Partner for Development: The Need for Effective Consultation Between the WTO \& NGOs, 28 BROOK. J. INT'L L. 937, 982 (expressing concern that freely allowing amicus briefs before the WTO's Dispute Settlement Body will work to the advantage of "well-funded industry or corporate groups"); Riva Krut, Globalization and Civil Society: NGO Influence in International Decision-making, United Nations Research Institute for Social Development Discussion Paper No. 83, text at nn. 60-62 (Geneva, April 1997); Mattner, supra note_ at 137-39 (noting the disproportionate influence of commercial lobbies in the WTO).

210 See Jeffords, Turning the Protester into a Partner for Development, supra note__ at 954 (noting that, over the course of the WTO's first four Ministerial meetings, 1195 of the 1533 NGOs attending were from North America or Europe and only 70 were from Latin America or Africa); Krut, Globalization and Civil Society, supra note_text at nn. 40-44; Mattner, supra note__ at 137-39 (noting the disproportionate influence of northern NGOs in the WTO); Andrea Kupfer Schneider, Unfriendly Actions: The Amicus Brief Battle At The WTO, 7 WID. L. SYMP. J. 87, 105 (arguing that a system of amicus briefs in WTO dispute resolution proceedings will work to the advantage of northern NGOs and the cause of "ecoimperialism").

${ }^{211}$ See Robert O. Keohane \& Joseph S. Nye, Jr., Redefining Accountability for Global Governance, in GOVERnANCE In a GLOBAl ECONOMY: POLITICAL AUTHORITY In TRANSITION 386, 388, 397 (Miles Kahler \& David A. Lake eds., 2003) (stating that electoral accountability in international governance is weak because of long chain of delegation running from national voting publics to heads of state and international organizations); Antonio F. Perez, Who Killed Sovereignty? Or: Changing Norms Concerning Sovereignty in International Law, 14 WIS. INT'L L. J. 463 (1996) (lamenting lack of democratic control of informal transnational networks); Martin Shapiro, Administrative Law Unbounded: Reflections on Government and Governance, 8 IND. J. GLOB. L. STUD. 369 (2001) (noting lack of national executive branch control over transnational regulatory networks); Edward T. Swaine, The Constitutionality of International Delegations, 104 Colum L. Rev. 1492, 1563-65 (noting that delegations to international institutions are further removed from national voters than delegations to national administrative agencies). See also CAROL HARLOW, ACCOUNTABILITY IN THE EUROPEAN UNION 79-92 (2002) (analyzing lack of national parliamentary control over EU decisionmaking); Juliet Lodge, The European Parliament, in THE EuROPEAN UnION: HOW DEMOCRATIC Is IT? (Svein S. Anderson \& Kjell A. Eliassen eds., 1996) (blaming national executives for intentionally marginalizing national parliaments in EU policymaking).
} 
Corporatist democracy's balance between associationalism and elected officials is better-suited to the global politics of today. Given the separation between public officials in the global sphere and voters and elected politicians in the national realm, such officials should be required to solicit the views of associations. The case for interest representation in international organizations would hold even in the face of a cosmopolitan Global People's Assembly. A directly elected assembly, or a series of such assemblies in specific international regimes, would be unlikely to satisfy current understandings of democratic representation. A global assembly's world-wide scale, together with the practical limits on the assembly's size, would mean that each legislator would represent an enormous constituency. Such a distance between voters, their representatives, and the assembly's collective output would test severely the contemporary concept of representative democracy. Therefore, even a cosmopolitan international order--one that served global citizens, not states--would need to supplement the public law of French-style republican democracy with other institutions. One possibility would be an elaborate, federalist system of local, national, regional, and global assemblies with carefully allocated powers. Another is the one explored in this Article--representation of citizens based not on territory, but on common interests and identities.

Representation of interest should follow a corporatist, not pluralist, mold. Unlike pluralist democracies, resources are so unevenly distributed in global politics that we cannot assume all will be able to mobilize and to compete, thereby generating the public good. As in the corporatist tradition, international officials should seek to understand which associations represent significant social and economic forces and to take their views into account. Public officials should take pains to ensure balance among those associations that can legitimately claim to represent large number of citizens, united by common social and economic interests. Just because certain businesses, in some sectors of the economy, can command the profits necessary to organize at the international level, does not signify that they should have a special voice in global governance. The same is true for professional advocacy groups that have the skills necessary to apply for foundation funding but do not have large memberships or that come from wealthy northern countries. Not to say that such interest groups should be excluded from international policymaking. Their views, however, should be moderated by those of other groups that do not have the resources to attend international treaty negotiations, lobby international regulatory committees, and file briefs before international tribunals.

What shape might this form of mediated civil society participation take? As the reader will recall, the corporatist model--illustrated by the German system--enables intermediate associations to participate in policymaking through a number of procedures. Committees of associational representatives are consulted on legislative and administrative measures; industry and professional associations are entrusted with regulatory functions, subject to requirements of 
representation of outside groups and supervision by the courts; certain associations are allowed to enforce public interest statutes by bringing lawsuits. Let us conduct a thought experiment. Transpose one piece of the corporatist model to one international organization: sector-specific advisory committees of associational representatives at the WTO. Such committees could be created in areas such as manufacturing, agriculture, consumer policy, the environment, and development. One example has been suggested by Dan Esty--an advisory committee of environmental and business interests that sits alongside the intergovernmental Committee on Trade and the Environment. These civil society committees would be consulted on revisions to the WTO Agreements in WTO Ministerials and on interpretations of those agreements issued by the WTO's specialized intergovernmental committees. Civil society committees would have a right to meet with government officials about proposals, to submit written papers on proposals, and to publish their reactions to the policies ultimately adopted; they would not have veto power or the power to vote. Government officials could reject their views but, to the extent that such views were well-substantiated, at the peril of public opprobium.

Imagining this form of corporatist interest representation at the global level is difficult for a number of reasons, some of which are unique to an international setting, others of which are instrinsic to the corporatist model wherever it operates. The most significant conceptual hurdle in making the transition from the domestic to the international realm is selecting the associations that would be entitled to representation. How would the associations sitting on WTO advisory committees be chosen? If governments were allowed to select from their national associations, then the moral premise of liberalism that has guided this entire analysis would suffer. Many societies do not recognize liberalism's limits on state authority, limits that are vital to the existence of civil society. For this reason, such societies are less likely to have interest associations. Moreover, illiberal governments are likely to select associations that represent state interests, not independent social and economic interests. But neither is the solution to give the task to an official in the WTO secretariat. The whole point of corporatist interest representation is to enable significant social and economic forces to take part in public decisionmaking. What is "significant" cannot be decided by a civil servant sitting in Geneva, removed from the complicated social realities of different parts of the world.

One provisional solution would be for regional organizations--the African Union, Organization of American States, Association of South East Asian Nations, and others--to appoint the civil society associations entitled to send representatives to WTO advisory committees. Most regions of the world contain a number of different regimes, some more liberal than others; by requiring a group of states to come to agreement, the difficulty of creating liberal global governance out of illiberal states is reduced somewhat. Moreover, this arrangement has the advantage of giving the choice to government officials 
familiar with the local cultures to be represented. Politicians and bureaucrats at the regional level should have a better understanding of their social and economic realities than civil servants in international bureaucracies. Tasking regional organizations with the choice of associations would also have a practical advantage. Each region could have the right to name four associations to each sector-specific committee. This committee structure, with its natural limit on membership numbers, would render the deliberations of WTO advisory committees far more manageable than if members were chosen by individual states.

Another set of challenges is related to the defects of corporatism domestically and the importance of attempting to avoid such defects at the international level. Again, at the heart of the matter is the selection of associations. At any historical moment, it might be clear which social forces have mobilized successfully in democratic politics and hence are entitled to influence directly public policy. But societies change. The special rights fairly granted to certain groups and their associations at one point in time, might become unjust privileges at a future point in time. As group members become preoccupied with new interests and identities and defect to other organizations, corporatist systems of interest representation can become obsolete. One oft-cited example of this phenomenon is the continuing prominence of blue collar unions in European politics notwithstanding their dwindling membership figures. Furthemore, any system that allows private associations to participate in policymaking, even a pluralist one, will lend state resources to those associations that succeed in advancing their goals through the process. In corporatist systems this dynamic is more apparent than in pluralist ones--although not necessarily more prevalent--because certain groups are empowered by law to contribute to policymaking. To avoid these defects, corporatist procedures at the international level should be designed to facilitate adaptation and flexibility. Every five to ten years, on a staggered basis, regional organizations would be asked to review their appointment of associations to WTO advisory committees. And to combat the danger of empowering, unfairly, one set of social actors over another set, regional organizations could be required to replace at least one out of their four associations during their periodic reviews.

This thought experiment can also incorporate some of the policy implications of the political philosophy of civil society. The goal of cosmopolitan mobilization should be taken into account in designing WTO advisory committees; trasnational associations should be represented too. The WTO secretariat could be charged with the selection task. Its civil servants are particularly well-placed to determine which associations are genuinely transnational in their activities and likely, therefore, to promote civic consciousness across national borders. Certain criteria could guide the appointments process: for instance, transnational associations that count 50,000 members in over thirty countries. Finally, in line with corporatist systems 
nationally, public funding for needy associations should be made available by the WTO and should be administered by the WTO secretariat. The purpose of designing a corporatist committee system is to guarantee balance in a global community in which interest group activity appears imbalanced. Ensuring that the members of such a committee system have the material resources necessary to participate effectively in committee work is part and parcel of creating the conditions for equal voice.

The argument for mediating the influence of interest associations, based on the realities of transnational associational life and representative democracy, also holds true in the European Union. Today the associational landscape of Brussels is more densely populated than before and a directly elected legislative assembly--the European Parliament--now exercises significant lawmaking and oversight responsibilities. Nevertheless, the European political space continues to display some of same characteristics as purely international regimes. Small, sector-specific industry associations and multinationals are better organized than nationwide employer associations, consumers groups, and human rights organizations. ${ }^{212}$ The European Parliament is directly elected but not directly accountable. Citizens largely ignore the activities of their European parliamentarians; national politics and political identities still take precedence over the nascent pan-European public sphere. ${ }^{213}$

National governments and the European Commission already play a significant role in deciding which associations should participate directly in policymaking. ${ }^{214}$ National governments choose the producer groups, labor unions, farmer organizations, and consumer associations that sit on the Economic and Social Committee. The Commission selects the pan-European federations that sit on numerous issue-specific advisory committees. This tradition of interest mediation should inform the Principle of Participatory Democracy guaranteed under Article I-47 of the Constitutional Treaty. European Courts should be wary of interpreting Article I-47 as a legal right to comment on

\footnotetext{
212 See Alan Cawson, Big Firms as Political Actors: Corporate Power and the Governance of the European Consumer Electronics Industry, in PARTICIPATION AND POLICYMAKING IN THE EUROPEAN UNION 185 (Helen Wallace \& Alasdair R. Young eds., 1997) (arguing that small clusters of multinationals more powerful than employers' associations); Maria Green Cowles, The Transatlantic Business Dialogue and Domestic Business-Government Relations, in TRANSFORMING EUROPE: EUROPEANIZATION AND Domestic Change (Maria Green Cowles, James Caporaso \& Thomas Risse eds., 2001) (describing advantages of single European companies over European and national employers associations in dealings with European Commission); CARLO RuZZA, EurOPE AND CIVIL SOCIETY 5-7 (2004) (describing traditional bias toward business interests but growing importance today of public interest associations); Alasdair R. Young, Consumption Without Representation? Consumers in the Single Market, in PARTiCIPATION AND POLICYMAKING IN THE EUROPEAN UNION 206 (Helen Wallace \& Alasdair R. Young eds., 1997) (describing organizational difficulties of European consumer movement).

${ }^{213}$ See Judge \& EARNSHAW, THE EUROPEAN PARLIAMENT supra note_ at 76, 112-13.

214 See Stijn SMISMANS, LAW, LEGITIMACY, AND EUROPEAN GOVERNANCE: FunCTIONAL PARTICIPATION IN SOCIAL REGULATION (2004).
} 
public policy measures, available to all citizens and their associations and enforceable in the courts. This would come close to the law of pluralist democracy and may not be suited to the realities of European governance. Rather, to further the cosmopolitan ideal, associations that have numerous members scattered throughout Europe and that seek to encourage debate on European political issues should play an important policymaking role.

Moreover, the organizations that national governments deem important in public life because of their long-standing histories and membership figures-some of which already sit on the Economic and Social Committee--should be given special consideration in European legislative and administrative processes.

In designing civil society participation, global policymakers should bear in mind that just as patterns of interest representation vary significantly within national systems of government, different forms of accommodation might be appropriate across international organizations or international policy areas. For instance, certain issues might provoke such extensive global mobilization that pluralist institutions are appropriate. Or national legislatures and executive branches might track certain forms of global governance so carefully that it might be proper to limit the role of civil society, as in the republican model. Or the public's desire for swift and decisive government action might be such that civil society participation should be restricted.

\section{Conclusion}

For global politics to become democratic politics, it is critical that citizens throughout the world debate and band together on the issues being decided in the many sites of global governance. Yet that basic liberal intuition does not necessarily support the conclusion that the associations through which citizens mobilize should participate in policymaking. This Article demonstrates that liberal theories of civil society advance the cause of specific types of associations: local associations with grassroots followings in the social capital and communitarian schools of thought and transnational membership associations for cosmopolitans. Ongoing reform efforts in organizations like the World Bank and the WTO should pay special attention to these forms of civil society.

Architects of international organizations can also draw inspiration from national experiences with democracy. Democratic societies have devised at least three ways of accommodating interest and identity groups in public life: pluralism, corporatism, and republicanism. Each embodies a specific set of values and beliefs about public life. Proving these popular theories of democracy right or wrong in their native soil is not feasible. It is possible, however, to discern whether their belief systems have any purchase on the contemporary realities of politics in the international realm. In a global world of poorly organized interests and ineffective electoral politics, the premises of neither the pluralist nor the republican models are satisfied. The laws and institutions of pluralist and republican democracy, when transposed to this new global terrain, 
would fall short of the ideals and aspirations of those political communities. The public law of corporatist democracy is a good alternative. Corporatist democracy's belief that only certain intermediate associations are legitimate participants in policymaking, alongside elected officials and civil servants, is better-suited to some of the realities of contemporary global politics. 